\title{
On the Chemical Profile of Marine Organisms from Coastal Subtropical Environments: Gross Composition and Nitrogen-to-Protein Conversion Factors
}

\author{
Graciela S. Diniz, Elisabete Barbarino and Sergio O. Lourenço \\ Universidade Federal Fluminense, Departamento de Biologia Marinha, \\ Niterói, RJ \\ Brazil
}

\section{Introduction}

After more than a century of predominance of more traditional studies in marine biology (e.g. ecology, reproduction, distribution, feeding, taxonomy), in the last decades the scientific community has been diversifying tremendously research approaches (Duarte et al., 2011). In this context, studies on the chemical composition of marine organisms have been becoming more common in the world (e.g. Amsler, 2009; Hedges et al., 2002; Janecki \& Rakusa-Suszczewski, 2004). Information on chemical characteristics can offer important subsidies for the study of physiology, biochemistry, ecology, and conservation of marine species, for example (Barbarino \& Lourenço, 2009), as well as in applied science.

Despite the recognition of the importance of data on the chemical composition of organisms in marine biology, there are still significant constraints in the basic knowledge of species, especially in tropical and subtropical environments. Studies in this field are very necessary to fulfill the existing gap. Data on the chemical components of the primary metabolism (such as nitrogen, phosphorus, protein, carbohydrate and lipid) are not available for many species, especially for non-edible organisms (Barbarino \& Lourenço, 2009).

Nitrogen is an essential element which is incorporated into fundamental macromolecules of the primary metabolism, such as proteins, peptides, nucleic acids, pigments and amino acids (Karl et al., 2002). Phosphorus is a key component of the ATP and many molecules, such as phospholipids. Information on the tissue concentrations of nitrogen and phosphorus allows interpretations on the availability of dissolved inorganic nutrients in the environment, especially when primary producers are analyzed (Lobban \& Harrison, 1994).

Proteins exert fundamental roles in all biological processes: enzymatic catalysts, transport and storage of substances, movements, mechanical support, immunological protection, generation and transmission of nerve impulses, control of growth and cell differentiation (Zaia et al., 1998). The amino acids are the basic structural units of the proteins. Carbohydrates exert a structural role in the cells and act as a reserve of chemical energy. They are particularly abundant in plant materials. Lipids have important functions in the cells, as structural components of biological membranes, reserve of chemical energy, and 
diverse metabolic activities, such as activation of enzymes and participation in the transport of electrons, for example (Carvalho \& Recco-Pimentel, 2007).

Moreover, measurements of proteins, carbohydrates and lipids have important applications in to characterize organisms which serve as food (Tacon et al., 2009). Chemical characterization of macromolecules of marine organisms are also very relevant for other applied uses, such as in industry, agriculture, aquaculture and health care.

The need for data on the chemical composition of marine organism is evident, but some methodological constraints still limit the progress in this field. In general, many basic chemical analyses must be adapted to the characteristics of the marine organisms, regarding the effects of moisture, salt content and differences in algae cell wall composition, for example (Barbarino \& Lourenço, 2009). This is particularly relevant in protein analysis, because differences procedures used for protein extraction establish remarkable influence on final results.

Some of the most common methods used for protein determination in marine organisms, Lowry's method (Lowry et al., 1951) and Bradford method (Bradford, 1976), are subject to interferences from many factors. The interferences are a consequence of the effects of some substances on specific amino acids, since that the chemical reactions which produce the protein quantification depends on the reactivity of the amino acid side groups (Legler et al., 1985). By contrast, the total nitrogen analysis is relatively simple and easy to perform, and nitrogen-to-protein conversion factors (N-Prot factors) can be used to estimate the crude protein content. The use of N-Prot factors has some important advantages if compared to other methodologies: accuracy, low cost and no need of a laborious protein extraction before the analysis.

A few studies on the protein content of marine organisms used N-Prot factors. In addition, the factor predominantly used in these studies was the traditional factor 6.25 , calculated by Jones (1931) from bovine muscles. The use of the factor 6.25 is based on two assumptions: i) that the average protein contains about 16 percent nitrogen by weight $(6.25 \times 16=100)$ (Tacon et al., 2009); and ii) that an insignificant amount of non-protein nitrogen (NPN) is present in the samples (Coklin-Brittain et al., 1999). However, the percentage of nitrogen in protein depend on the amino acid composition, which is variable from one protein source to another, and in practice a variation of between 12 and 19 percent nitrogen is possible between individual proteins (Tacon et al., 2009). Moreover, several organisms contain high concentrations of other nitrogenous compounds, such as nucleic acids, amines, urea, inorganic intracellular nitrogen, vitamins and alkaloids (Lourenço et al., 2004). The contribution of non-protein nitrogenous compounds to the total crude protein content of different kinds of marine biological samples ranges from $10 \%$ to $40 \%$, according to Venugopal \& Shahidi (1996).

The use of specific N-Prot factors is widely recommended in order to get more accurate estimates of protein content (Sosulski \& Imafidon, 1990). The nitrogen:protein ratio does vary according to the source considered (Mariotti et al., 2008). The use of N-Prot factors is particularly wide in food science, such as certain cereals (e.g 5.26 for rise, 5.47 for wheat; Fujihara et al., 2008), legumes (e.g. 4.75-5.87 for cassava root; Yeoh \& Truong, 1996), mushroom (4.70; Mattila et al., 2002), and fish and fish products (4.94, Salo-Väänänen \& Koivistoinen, 1996), among other products. The use of N-Prot factors is still unusual in sea science, possibly because most of the scientific community ignores this methodological alternative. 
The use of the factor 6.25, in case of NPN-rich samples, tends to overestimate the protein data. Despite this, several authors continue to use the factor 6.25 to estimate the protein content of aquatic organisms (e.g. Nurnadia et al., 2011; Undeland et al., 1999; Zaboukas et al., 2006). Except for a short list of specific N-Prot factors available for marine organisms, the general factor 6.25 is still used for most plant and animal sources from the sea.

The purpose of this study was to determine specific N-Prot factors for 23 species of marine organisms from coastal areas of Rio de Janeiro State, Brazil, based on the ratio of amino acid composition to total nitrogen (TN) content. In addition, we also characterized and compared the organisms regarding their carbohydrate, lipid, nitrogen and phosphorus contents.

\section{Material and methods}

\subsection{Organisms and sampling}

The organisms studied in this work were collected at different locations in the State of Rio de Janeiro, distributed by the municipalities of Arraial do Cabo, Armação dos Búzios, Niteroi, Rio de Janeiro and Angra dos Reis (Figure 1). The organisms were chosen regarding their local abundance and taxonomic diversity, including species that live in the transition between land and sea. Seaweeds, spermatophytes, invertebrates and fishes were assessed in this study, totalizing 23 species (Table 1).

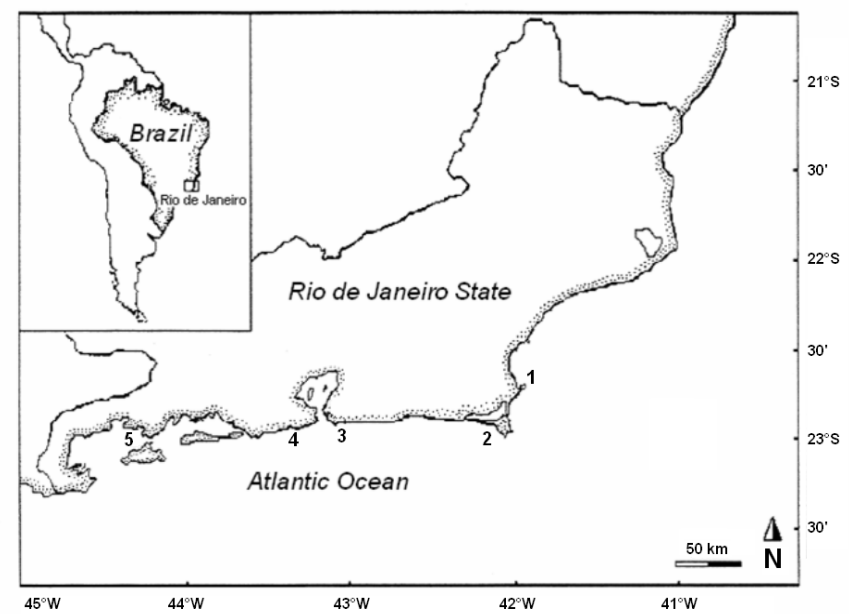

Fig. 1. Sampling sites in Rio de Janeiro State, Brazil: Armação dos Búzios (1), Arraial do Cabo (2), Niterói (3), Rio de Janeiro (4) and Angra dos Reis (5).

Red (Asparagopsis taxiformis and Centroceras clavulatum), green (Chaetomorpha aerea) and brown (Sargassum filipendula) algae were analyzed. Whole thalli of adult seaweeds were collected and washed in the field with local seawater in order to remove epiphytes, sediment and organic matter. Plants were packed in plastic bags and kept on ice until returned to the laboratory, where the samples were gently brushed under running seawater, rinsed with distilled water, dried with paper tissue and frozen at $-18^{\circ} \mathrm{C}$. Subsequently, the samples were freeze dried in a Terroni Fauvel, model LB1500TT device. Statistically, each seaweed sample resulted of more than a single specimen, because of the small size of the individuals. 


\begin{tabular}{|c|c|c|}
\hline Organisms & Family & Sampling sites \\
\hline \multicolumn{3}{|l|}{ Seaweeds } \\
\hline $\begin{array}{l}\text { Asparagopsis taxiformis (Delile) Trevisan de } \\
\text { Saint-Léon, } 1845\end{array}$ & Bonnemaisoniaceae & Angra dos Reis \\
\hline $\begin{array}{l}\text { Centroceras clavulatum (C. Agardh) Montagne, } \\
1846\end{array}$ & Ceramiaceae & Arraial do Cabo \\
\hline Chaetomorpha aerea (Dillwyn) Kützing, 1849 & Cladophoraceae & Arraial do Cabo \\
\hline Sargassum filipendula (Agardh, 1824) & Sargassaceae & Arraial do Cabo \\
\hline \multicolumn{3}{|l|}{ Spermatophytes } \\
\hline Acrostichum aureum (Linnaeus, 1753) & Polypodiaceae & Rio de Janeiro \\
\hline $\begin{array}{l}\text { Avicennia schaueriana (Stapft \& Leechman) } \\
\text { Moldenke, } 1939\end{array}$ & Avicenniaceae & Rio de Janeiro \\
\hline Blutaparon portulacoides (St. -Hill) Mears, 1982 & Amaranthaceae & Rio de Janeiro \\
\hline Halodule wrightii (Ascherson, 1868) & Cymodoceaceae & Arm. Búzios \\
\hline $\begin{array}{l}\text { Laguncularia racemosa (Linnaeus) Gaertner, } \\
1807\end{array}$ & Combretaceae & Rio de Janeiro \\
\hline Ruppia maritima (Linnaeus, 1753) & Ruppiaceae & Rio de Janeiro \\
\hline $\begin{array}{l}\text { Spartina alterniflora (Loiseleur-Deslongchamps, } \\
\text { 1807) }\end{array}$ & Poaceae & Rio de Janeiro \\
\hline Typha domingensis (Persoon) Steudel, 1807 & Typhaceae & Rio de Janeiro \\
\hline \multicolumn{3}{|l|}{ Invertebrates } \\
\hline Aplysia brasiliana (Rang, 1828) & Aplysiidae & Arm. Búzios \\
\hline Bunodossoma caissarum (Correa, 1964) & Actiniidae & Arraial do Cabo \\
\hline Desmapsamma anchorata (Carter, 1882) & Desmacidadae & Angra dos Reis \\
\hline $\begin{array}{l}\text { Echinaster (Othilia) brasiliensis (Muller \& } \\
\text { Troschel, 1842) }\end{array}$ & Echinasteridae & Angra dos Reis \\
\hline Echinometra lucunter (Linnaeus,1758) & Echinometridae & Arraial do Cabo \\
\hline Eledone massyae (Voss, 1964) & Octopodidae & Arraial do Cabo \\
\hline \multicolumn{3}{|l|}{ Fishes } \\
\hline Dactylopterus volitans (Linnaeus, 1758) & Dactylopteridae & Niterói \\
\hline Genypterus brasiliensis (Regan, 1903) & Ophidiidae & Arraial do Cabo \\
\hline Mullus argentinae (Hubbs \& Marini, 1933) & Mullidae & Arraial do Cabo \\
\hline Rhizoprionodon lalandii (Muller \& Henle, 1839) & Carcharhinidae & Niterói \\
\hline Rhizoprionodon porosus (Poey, 1861) & Carcharhinidae & Niterói \\
\hline
\end{tabular}

Table 1. Organisms studied, with indication of taxonomic details and sampling sites in Rio de Janeiro State, Brazil. Arm. Búzios = Armação dos Búzios.

The spermatophytes analyzed here included two mangrove plants (Laguncularia racemosa and Avicennia schaueriana), one salt marsh plant (Spartina alterniflora), two wetland plants (Acrostichum aureum and Typha domingensis), a sand dune plant (Blutaparon portulacoides), and two seagrasses (Halodule wrightii and Ruppia maritima). Only mature and healthy leaves were used in this study: both young and senescent leaves were not collected. Leaves were collected and prepared similarly to the description presented for seaweeds. Each statistical sample resulted from leaves collected from a single plant. 
Six species of marine invertebrates belonging to four phyla were analyzed: Desmapsamma anchorata (Porifera), Bunodossoma caissarum (Cnidaria), Aplysia brasiliana, Eledone massyae (Mollusca), Echinaster brasiliensis and Echinometra lucunter (Echinodermata). The animals were collected in the inter-tidal region or by free diving in small depths $(<5.0 \mathrm{~m})$. The animals were washed in the field with seawater, packed in plastic bags and kept on ice until returned to the laboratory. In the laboratory samples were washed with distilled water, cut, frozen and freeze-dried. Internal soft parts of the bodies were used for echinoderms, and for mollusks only the mantle was used. For other invertebrates (e.g. sponge) whole bodies were processed. Each statistical sample resulted from a single individual.

Five species of not-sexed adult fishes (with similar body sizes) were collected with bottom trawls and washed and transported as described for the invertebrates. In the laboratory samples were cut and only the muscles were used. Each statistical sample resulted from a single individual.

For all samples, the freeze-dried material was powdered manually using a mortar and pestle, and it was kept in desiccators containing silica-gel, under vacuum and at room temperature, until the chemical analyses were carried out. Four statistical samples were prepared for each species assessed in this study.

\subsection{Chemical analyses}

Total nitrogen and phosphorus were determined after peroxymonosulphuric acid digestion, using a Hach digestor (Digesdhal ${ }^{\circledR}$, Hach Co.). Total N and P contents were determined spectrophotometrically, following analytical details provided by Lourenço et al. (2005).

The Lowry's method (Lowry et al., 1951) was used to analyze hydrosoluble protein in the samples, using bovine serum albumin as a protein standard. Spectrophotometric determinations were performed at $750 \mathrm{~nm}, 35 \mathrm{~min}$ after the start of the chemical reaction. Total carbohydrate was extracted with $80 \% \mathrm{H}_{2} \mathrm{SO}_{4}$, according to Myklestad \& Haug (1972). The carbohydrate concentration was determined spectrophotometrically at $485 \mathrm{~nm}, 30 \mathrm{~min}$ after the start of the chemical reaction, by the phenol-sulfuric acid method (Dubois et al., 1956), using glucose as a standard. Total lipid was extracted according to Folch et al. (1957), and determined gravimetrically after solvent (chloroform) evaporation.

Total amino acid (AA) was determined by high performance liquid chromatography with pre-column derivatization with AccQ.Fluor ${ }^{\circledR}$ reagent (6-aminoquinolyl- $N$ hydroxysuccinimidyl carbamate), reverse phase column $\mathrm{C}_{18}$ AccQ.Tag ${ }^{\circledR}$ Nova-Pak (150x3.9 $\mathrm{mm} ; 4 \mu \mathrm{m}$ ), ternary mobile phase in gradient elution composed by sodium acetate $140 \mathrm{mM}+$ TEA $17 \mathrm{mM} \mathrm{pH} 5.05$ (solvent A), acetonitrile (solvent B) and water (solvent C), flow 1 ml.min ${ }^{-1}$ (Cohen \& De Antonis, 1994). A Waters, model Alliance 2695 chromatograph was used, equipped with a fluorescence detector Waters ${ }^{\circledR} 2475\left(\mu_{\text {ex. }} 250 \mathrm{~nm}, \mu_{\text {em. }} 395 \mathrm{~nm}\right)$. Analytical conditions were suitable to determine all amino acids, except tryptophan, cysteine + cistine and methionine. The percent of nitrogen in each amino acid was used to calculate nitrogen recovered from total amino acid analysis. Aspartic acid, threonine, serine, glutamic acid, proline, glycine, alanine, valine, isoleucine, leucine, tyrosine, phenylalanine, histidine, lysine, and arginine contents were multiplied by $0.106,0.118,0.134,0.096,0.123$, $0.188,0.158,0.120,0.108,0.108,0.078,0.085,0.271,0.193$, and 0.322 , respectively (Diniz et al., 2011). The sum of amino acid residues was used to estimate total protein in the samples (Fujihara et al., 2008; Yeoh \& Truong, 1996). 


\subsection{Calculation of N-Prot factors}

$\mathrm{N}$-Prot factors were determined for each species by the ratio of amino acid residues (AARes) to total nitrogen (TN) of the sample: N-Prot factor = AA-Res / TN. Thus, for a $100 \mathrm{~g}$ (dry weight) sample having $16.21 \mathrm{~g}$ of amino acid residues and $3.48 \mathrm{~g}$ of TN, a N-Prot factor of 4.66 is calculated.

The amino acid residues of the samples was calculated by summing up the amino acid masses retrieved after acid hydrolysis (total amino acids), minus the water mass (18 $\mathrm{H}_{2} \mathrm{O} / \mathrm{mol}$ of amino acid) incorporated into each amino acid after the disruption of the peptide bonds (Fujihara et al., 2008).

\subsection{Statistical analysis}

The results were analyzed by one-way analysis of variance (ANOVA) with significance level $\alpha=0.05$, followed, where applicable, with a Tukey's multiple comparison test (Zar, 1996). The statistical analysis was applied within a given category of organisms (ex.: invertebrates), thus comparisons of chemical composition between seaweeds and fishes, for instance, were not performed.

\section{Results}

\subsection{Nitrogen and phosphorus}

The percentage of nitrogen showed wide variations among seaweeds, ranging from $1.75 \%$ (S. filipendula, a brown alga) to $5.56 \%$ (A. taxiformis) of the dry weight. Red algae showed higher total nitrogen concentrations in the thalli, with significant differences $(p<0.001)$ to the other algae (Table 2). The green alga $C$. aerea showed an intermediate concentration of $\mathrm{N}$ in comparison to red and brown algae. Spermatophytes also showed a great variation in the nitrogen concentration among the species. Values ranged from $0.99 \%$ (L. racemosa) to $3.83 \%$ (R. maritima). The highest concentrations of nitrogen were observed in seagrasses, followed by the wetland plant $T$. domingensis (Table 2).

The animals present more nitrogen concentration in their tissues than the photosynthetic organisms. In addition, remarkable variations in $\mathrm{N}$ concentrations were observed among the invertebrate species, ranging from $3.79 \%$ (D. anchorata, sponge) to $12.7 \%$ (E. massyae, an octopus). Fishes tended to show higher values of total N, ranging from $11.6 \%$ (M. argetinae) to $14.9 \%$ (R. porosus) of the d.w., with minor variations among the fish species (Table 2).

Wide concentrations of phosphorus occurred in seaweeds. C. clavulatum showed the highest value $(0.54 \%, p<0.001)$ and $S$. filipendula and $A$. taxiformis showed the lowest concentrations $(0.27 \%$ and $0.30 \%$ respectively). The lowest values for phosphorus were observed in spermatophytes, especially in the sand dune plant B. portulacoides $(0.13 \%)$. The seagrasses showed the highest phosphorus concentrations among the spermatophytes, circa $0.58 \%$.

The concentrations of phosphorus in animals were typically higher than in algae and plants. Values found for invertebrates showed wide variations, ranging from $0.41 \%$ in the sponge D. anchorata to $1.16 \%$ in the octopus E. massyae. Narrower variations in P concentrations were found in fishes, ranging from $0.94 \%$ (D. volitans) to $1.29 \%$ (G. brasiliensis).

\subsection{Hydrosoluble protein, carbohydrate and lipid}

The hydrosoluble protein contents in seaweeds ranged from $8.72 \%$ (S. filipendula) to $16.1 \%$ (C. aerea) of the d.w. with intermediate and similar concentrations $(p>0.05)$ in the red algae. 
The concentrations of hydrosoluble protein also varied widely among spermatophytes. Peaks were found in $T$. domingensis $(21.4 \%, p<0.001)$ and the seagrass $H$. wrightii showed the lowest concentrations (4.94\%). Wide variations in protein content were recorded for the invertebrates, with lower values in the sponge $D$. anchorata $(12.2 \%)$ and highest percentages in the octopus E. massyae (47.6\%). Contents of hydrosoluble protein were similar among the fish species, always higher than $45 \%$ of the dry weight (Table 2 ).

\begin{tabular}{|c|c|c|c|c|c|}
\hline $\begin{array}{l}\text { Groups / } \\
\text { species }\end{array}$ & $\begin{array}{c}\text { Total } \\
\text { Nitrogen }\end{array}$ & $\begin{array}{c}\text { Total } \\
\text { Phosphorus }\end{array}$ & $\begin{array}{l}\text { Hydrosoluble } \\
\text { protein }\end{array}$ & $\begin{array}{c}\text { Total } \\
\text { Carbohydrate }\end{array}$ & Total lipid \\
\hline Seaweeds & $* * *$ & $* * *$ & $* * *$ & $* * *$ & ** \\
\hline A. taxiformis & $5.56 \pm 0.29 a$ & $0.30 \pm 0.04 \mathrm{c}$ & $11.7 \pm 0.58^{b}$ & $22.9 \pm 1.35^{b}$ & $4.80 \pm 0.24^{b}$ \\
\hline C. clavulatum & $4.63 \pm 0.15^{b}$ & $0.54 \pm 0.03 \mathrm{a}$ & $11.3 \pm 0.64^{b}$ & $27.1 \pm 1.73^{\mathrm{a}}$ & $2.78 \pm 0.23 c$ \\
\hline C. aerea & $2.56 \pm 0.13^{c}$ & $0.43 \pm 0.04^{b}$ & $16.1 \pm 0.25^{\mathrm{a}}$ & $29.4 \pm 0.78^{a}$ & $5.49 \pm 0.09^{a}$ \\
\hline S. filipendula & $1.75 \pm 0.03^{\mathrm{d}}$ & $0.27 \pm 0.02 c$ & $8.72 \pm 0.54^{c}$ & $16.8 \pm 0.97 c$ & $2.92 \pm 0.13^{c}$ \\
\hline Spermatophytes & $* * *$ & $* * *$ & $* * *$ & $* * *$ & $* * *$ \\
\hline H. wrightii & $2.72 \pm 0.09 \mathrm{~b}$ & $0.57 \pm 0.18^{\mathrm{a}}$ & $4.94 \pm 0.29 f$ & $19.0 \pm 1.17 \mathrm{~d}$ & $4.14 \pm 0.33 c$ \\
\hline R. maritima & $3.83 \pm 0.04^{\mathrm{a}}$ & $0.59 \pm 0.02^{\mathrm{a}}$ & $6.44 \pm 0.30^{e}$ & $26.8 \pm 0$ & $6.11 \pm 0.53^{a}$ \\
\hline A. aureum & $1.73 \pm 0.06^{c}$ & $0.21 \pm 0.01^{b}$ & $12.7 \pm 0.52^{c}$ & $24.2 \pm 0.99 c$ & $4.69 \pm 0.39 c$ \\
\hline B. portulacoides & $1.75 \pm 0.10^{c}$ & $0.13 \pm 0.01^{c}$ & $7.73 \pm 0.17 \mathrm{e}$ & $20.3 \pm 0.58^{\mathrm{d}}$ & $3.71 \pm 0.22^{\mathrm{d}}$ \\
\hline T. domingensis & $2.51 \pm 0.10^{b}$ & $0.16 \pm 0.01^{c}$ & $21.4 \pm 1.05^{\mathrm{a}}$ & $35.8 \pm 1.81^{\mathrm{a}}$ & $5.34 \pm 0.54^{b}$ \\
\hline A. schaueriana & $1.95 \pm 0.07 c$ & $0.14 \pm 0.01^{c}$ & $9.53 \pm 0.34^{\mathrm{d}}$ & $19.1 \pm 1.21^{\mathrm{d}}$ & $6.76 \pm 0.54^{a}$ \\
\hline L. racemosa & $0.99 \pm 0.19 d$ & $0.14 \pm 0.05^{c}$ & $14.7 \pm 0.69 c$ & $9.68 \pm 0.70 \mathrm{e}$ & $6.07 \pm 0.51^{\mathrm{a}}$ \\
\hline S. alterniflora & $1.94 \pm 0.07 \mathrm{c}$ & $0.24 \pm 0.01^{b}$ & $17.0 \pm 1.00^{\mathrm{b}}$ & $22.4 \pm 1.74^{\mathrm{cd}}$ & $4.88 \pm 0.46^{c}$ \\
\hline Invertebrates & $* * *$ & $* * *$ & $* * *$ & $* * *$ & \\
\hline D. anchorata & $3.79 \pm 0.32 \mathrm{e}$ & $0.41 \pm 0.03 c$ & $12.2 \pm 0.69 \mathrm{e}$ & $4.67 \pm 0.26^{c}$ & $4.92 \pm 0.29 c$ \\
\hline B. caissarum & $9.71 \pm 0.36^{b}$ & $1.00 \pm 0.08^{\mathrm{a}}$ & $29.6 \pm 0.72^{b}$ & $6.88 \pm 0.61^{b}$ & $8.78 \pm 0.66^{b}$ \\
\hline A. brasiliana & $7.53 \pm 0.31^{c}$ & $0.84 \pm 0.05^{b}$ & $25.4 \pm 1.35^{c}$ & $18.4 \pm 1.83^{a}$ & $5.02 \pm 0.40^{c}$ \\
\hline E. massyae & $12.7 \pm 0.50^{\mathrm{a}}$ & $1.16 \pm 0.03^{a}$ & $47.6 \pm 3.12^{\mathrm{a}}$ & $1.85 \pm 0.15^{\mathrm{d}}$ & $3.80 \pm 0.15^{\mathrm{d}}$ \\
\hline E. brasiliensis & $7.62 \pm 0.15^{c}$ & $0.86 \pm 0.04^{b}$ & $24.7 \pm 1.57 \mathrm{~cd}$ & $3.70 \pm 0.25 c$ & $25.3 \pm 1.09 \mathrm{a}$ \\
\hline E. lucunter & $5.42 \pm 0.32 \mathrm{~d}$ & $0.82 \pm 0.23 b$ & $22.5 \pm 2.69 \mathrm{~d}$ & $7.22 \pm 0.12^{b}$ & $8.59 \pm 0.92^{b}$ \\
\hline Fishes & $* * *$ & *** & $* * *$ & $* * *$ & $* * *$ \\
\hline D. volitans & $11.7 \pm 0.23^{b}$ & $0.94 \pm 0.05^{\mathrm{d}}$ & $47.1 \pm 1.32^{b}$ & $3.45 \pm 0$ & $7.81 \pm 0.84^{b}$ \\
\hline G. brasiliensis & $14.0 \pm 0.67 \mathrm{a}$ & $1.29 \pm 0.08^{\mathrm{ab}}$ & $56.0 \pm 1.79 a$ & $1.11 \pm 0.03^{\mathrm{de}}$ & $8.28 \pm 0.72^{b}$ \\
\hline M. argentinae & $11.6 \pm 0.72^{b}$ & $1.12 \pm 0.08^{c}$ & $47.7 \pm 2.24^{b}$ & $1.03 \pm 0.10 \mathrm{e}$ & $16.1 \pm 3.68^{a}$ \\
\hline R. lalandii & $14.4 \pm 0.41^{a}$ & $1.15 \pm 0.04^{b c}$ & $48.2 \pm 1.39 b$ & $1.40 \pm 0.09 b c$ & $4.40 \pm 0.37 c$ \\
\hline R. porosus & $14.9 \pm 0.28^{a}$ & $1.10 \pm 0.01^{\mathrm{cd}}$ & $45.7 \pm 0.30^{\mathrm{b}}$ & $1.17 \pm 0.04^{\text {cde }}$ & $5.28 \pm 0.33^{b c}$ \\
\hline
\end{tabular}

Table 2. Gross chemical composition of 23 species of marine organisms sampled in subtropical sites of Brazil. Values are expressed as percentage of the dry weight and represent the mean of four replicates \pm standard deviation $(n=4)$. Mean values significantly different: ${ }^{* *} p<0.001, \mathrm{a}>\mathrm{b}>\mathrm{c}>\mathrm{d}>\mathrm{e}$. Identical superscript letters $(\mathrm{a}, \mathrm{a} ; \mathrm{b}, \mathrm{b} ; \mathrm{c}, \mathrm{c})$ indicate that mean values are not significantly different.

Total carbohydrate was abundant in all photosynthetic organisms, typically achieving concentrations higher than $19 \%$ (except in the mangrove plant L. racemosa, with only $9.68 \%$ ), with a peak of $35.8 \%$ in the wetland plant $T$. domingensis. The seaweeds showed values ranging from $16.8 \%$ (S. filipendula) to $29.4 \%$ (C. aerea) of the d.w. Carbohydrate was the less abundant 
organic substance measured in all animals, except for sea slug A. brasiliana, which showed a high content of carbohydrate $(18.4 \%)$. In the other invertebrates, the values of carbohydrates ranged from $1.85 \%$ (E. massyae, octopus) to $7.22 \%$ (E. lucunter, sea urchin). In fish species, the low carbohydrate content ranged from $1.03 \%$ (M. argentinae) to $3.45 \%$ (D. volitans) of the d.w. Algae and plants exhibited low concentrations of lipid. In seaweeds, the peak was recorded in C. aerea (5.49\%, d.w.) and the lowest value occurred in C. clavulatum $(2.78 \%)(p<0.001)$. In spermatophytes the values ranged from $3.71 \%$ (B. portulacoides) to $6.76 \%$ (A. schaueriana). The concentration of lipid varied widely among the animals. In invertebrates, the values ranged from $3.8 \%$ in the octopus E. massyae to $25.3 \%$ in the starfish E. brasiliensis. In fishes, the lowest lipid concentrations were registered in elasmobranch fishes ( $R$. porosus and $R$. lalandii), with less than $5.5 \%$ of the d.w. M. argentinae showed a significantly higher lipid concentration $(16.1 \%)$ than the other species $(p<0.001)$.

\subsection{Amino acid composition}

In order to save space, results for the amino acid profiles presented in the Table 3 involve some selected organisms only.

In seaweeds, the highest concentration of glutamic acid (16.3\% of total amino acids) was found in S. filipendula, while A. taxiformis had the lowest (10.3\%). Aspartic acid was the second most abundant AA, varying from $9.59 \%$ (A. taxiformis) to $12.7 \%$ (C. aerea). Histidine was the less abundant amino acid in all species, and only $S$. filipendula achieved values close to $2 \%$. A taxiformis showed higher concentrations of valine, phenylalanine and arginine than the other seaweeds. Peaks of tyrosine were observed in C. clavulatum, with values close to $5 \%$. Percentages of leucine and threonine were similar among all seaweeds.

In spermatophytes, the highest concentration of glutamic acid (12.2\% of total amino acids) was found in the seagrass $R$. maritima, while the seagrass $H$. wrightii had the lowest $(9.26 \%)$ concentrations. Aspartic acid and leucine were other abundant amino acids. Histidine and tyrosine were the less abundant amino acids among the plant species. The concentration of proline was also high in the seagrass $H$. wrightii $(12.8 \%)$

The amino acid profiles were remarkably different among invertebrates. For the anemone $B$. caissarum, the octopus E. massyae and the starfish E. brasiliensis the major amino acid was arginine, with values ranging from $13.3 \%$ to $20.6 \%$. For the sea urchin E. lucunter, the sponge $D$. anchorata and the sea slug A. brasiliana the most abundant AA was glycine, with values ranging from $11.9 \%$ to $17.9 \%$. Glutamic acid was the second most abundant amino acid in all species and histidine and tyrosine were the less abundant.

Fish species showed similar amino acid profiles, with glutamic acid as the most abundant amino acid, which fluctuate from $12.5 \%$ (M. argentinae) and $14.8 \%$ (R. porosus). Fishes were also rich in lysine, with values fluctuating from $9.63 \%$ (D. volitans) to $10.7 \%$ ( $R$. porosus). The percentage of histidine was the lowest in all species, with an overall average value of $2.12 \%$. $D$. volitans showed the higher concentration of arginine $(11.0 \%)$ and the percentages of the other amino acids were typically similar among all species.

\subsection{Total protein and nitrogen-to-protein conversion factors}

The total protein content of the samples is showed in Table 4 as the sum of the total amino acid residues. Values of total protein were higher than hydrosoluble protein for most of the species analyzed (all animal samples), except for two seaweeds and five spermatophytes (Tables 2 and 4). The seaweeds showed wide variations in total protein concentrations, 
varying from $8.62 \%$ (S. filipendula) to $25.1 \%$ (A. taxiformis) of the d.w. Peaks of total protein in seaweeds were found in rhodophytes. For spermatophytes, concentrations of total protein varied from $5.56 \%$ (L. racemosa) to $19.2 \%$ (R. maritima).

The animals presented higher concentrations of total protein. For invertebrates, the values ranged from $19.4 \%$ (D. anchorata, sponge) to 66.7\% (E. massyae, octopus). Fishes showed higher total protein concentrations than invertebrates, with values varying from $66.2 \%(M$. argentinae) to $81.5 \%$ (G. brasiliensis) of the d.w.

\begin{tabular}{lcccccccc}
\hline \multirow{2}{*}{ Amino acids } & $\begin{array}{c}\text { C. } \\
\text { clavulatum }\end{array}$ & $\begin{array}{c}\text { R. } \\
\text { maritima }\end{array}$ & $\begin{array}{c}\text { A. } \\
\text { schaueriana }\end{array}$ & $\begin{array}{c}S \\
\text { alterniflora }\end{array}$ & $\begin{array}{c}\text { E. massyae } \\
\text { brasiliensis argentinae }\end{array}$ & R. lalandii \\
\hline Aspartic acid & $11.1 \pm 0.49$ & $12.8 \pm 1.17$ & $8.62 \pm 0.13$ & $9.68 \pm 0.15$ & $6.27 \pm 1.02$ & $7.97 \pm 0.49$ & $9.20 \pm 0.45$ & $8.96 \pm 0.12$ \\
Threonine & $5.24 \pm 0.11$ & $4.95 \pm 0.14$ & $5.35 \pm 0.04$ & $5.07 \pm 0.17$ & $4.39 \pm 0.51$ & $4.79 \pm 0.37$ & $4.44 \pm 0.13$ & $4.72 \pm 0.05$ \\
Serine & $5.15 \pm 0.06$ & $4.91 \pm 0.36$ & $4.48 \pm 0.19$ & $5.03 \pm 0.30$ & $6.04 \pm 1.33$ & $5.20 \pm 0.95$ & $4.32 \pm 0.08$ & $4.59 \pm 0.05$ \\
Glutamic acid & $11.8 \pm 0.39$ & $12.2 \pm 0.73$ & $9.78 \pm 0.14$ & $11.1 \pm 0.12$ & $9.34 \pm 0.97$ & $10.2 \pm 0.34$ & $12.5 \pm 0.17$ & $13.3 \pm 0.27$ \\
Proline & $4.95 \pm 0.18$ & $5.93 \pm 0.33$ & $5.40 \pm 0.09$ & $5.00 \pm 0.27$ & $5.54 \pm 0.44$ & $4.20 \pm 0.50$ & $3.63 \pm 0.08$ & $3.54 \pm 0.03$ \\
Glycine & $5.18 \pm 0.09$ & $6.60 \pm 1.75$ & $8.93 \pm 0.27$ & $6.42 \pm 1.52$ & $7.59 \pm 0.10$ & $5.40 \pm 1.98$ & $4.77 \pm 0.25$ & $5.14 \pm 0.16$ \\
Alanine & $6.76 \pm 0.14$ & $6.16 \pm 0.16$ & $6.30 \pm 0.03$ & $6.74 \pm 0.92$ & $5.55 \pm 0.33$ & $4.41 \pm 0.13$ & $6.14 \pm 0.02$ & $5.69 \pm 0.07$ \\
Valine & $6.18 \pm 0.17$ & $6.00 \pm 0.11$ & $6.84 \pm 0.03$ & $6.56 \pm 0.32$ & $5.11 \pm 0.18$ & $5.58 \pm 0.09$ & $5.68 \pm 0.08$ & $5.50 \pm 0.13$ \\
Isoleucine & $5.46 \pm 0.14$ & $5.10 \pm 0.41$ & $5.50 \pm 0.02$ & $5.33 \pm 0.16$ & $5.74 \pm 0.26$ & $4.90 \pm 0.15$ & $5.41 \pm 0.10$ & $5.76 \pm 0.09$ \\
Leucine & $7.39 \pm 0.18$ & $8.87 \pm 0.12$ & $9.84 \pm 0.05$ & $9.33 \pm 0.34$ & $8.77 \pm 0.35$ & $7.70 \pm 0.15$ & $8.74 \pm 0.15$ & $8.78 \pm 0.13$ \\
Tyrosine & $4.96 \pm 0.14$ & $3.69 \pm 0.58$ & $3.77 \pm 0.19$ & $3.80 \pm 0.58$ & $3.12 \pm 0.18$ & $4.10 \pm 0.35$ & $3.53 \pm 0.12$ & $2.45 \pm 0.08$ \\
Phenylalanine & $5.02 \pm 0.09$ & $6.13 \pm 0.48$ & $6.09 \pm 0.12$ & $6.04 \pm 0.11$ & $5.09 \pm 0.47$ & $5.38 \pm 0.41$ & $5.12 \pm 0.06$ & $5.73 \pm 0.01$ \\
Histidine & $1.84 \pm 0.17$ & $1.90 \pm 0.26$ & $1.94 \pm 0.03$ & $1.73 \pm 1.06$ & $1.05 \pm 1.00$ & $1.62 \pm 1.40$ & $2.48 \pm 0.07$ & $2.47 \pm 0.01$ \\
Lysine & $6.80 \pm 0.10$ & $6.15 \pm 0.16$ & $5.45 \pm 0.30$ & $6.22 \pm 0.94$ & $8.36 \pm 0.35$ & $7.68 \pm 0.63$ & $10.4 \pm 0.15$ & $10.6 \pm 0.14$ \\
Arginine & $7.31 \pm 0.09$ & $6.28 \pm 0.15$ & $7.17 \pm 0.20$ & $6.66 \pm 0.17$ & $17.9 \pm 4.68$ & $20.6 \pm 3.27$ & $10.2 \pm 0.08$ & $8.16 \pm 0.05$ \\
Total & $95.1 \pm 2.52$ & $97.6 \pm 6.93$ & $95.5 \pm 1.81$ & $94.7 \pm 7.12$ & $99.9 \pm 12.2$ & $99.8 \pm 11.2$ & $96.6 \pm 1.99$ & $95.4 \pm 1.39$ \\
\hline
\end{tabular}

Table 3. Total amino acid composition of eight organisms from coastal environments of Rio de Janeiro State, Brazil. Results are expressed as grams of amino acid measured in $100 \mathrm{~g}$ of protein and represent the actual recovery of amino acids after acid hydrolysis. Values are the mean of three replicates $\pm S D(n=3)$.

The Table 4 also presents the nitrogen mass within total amino acid (Amino acid-N), the percentage of $\mathrm{N}$ present in protein (protein-N) and the N-Prot factors calculated for each species. The relative percentage of protein nitrogen was estimated as the ratio of nitrogen recovered from amino acid (Table 4) to total nitrogen (Table 2). From the ratio of the mass of amino acid residues to total nitrogen specific N-Prot factors were calculated.

Nitrogen mass within total amino acid in seaweeds ranged from $1.36 \%$ (S. filipendula) to $4.14 \%$ (A. taxiformis). Protein nitrogen ranged from $69.5 \%$ (C. clavulatum) to $78 \%$ (S. filipendula) and the red algae tended to show higher percentages of non-proteinaceus nitrogen (NPN). The N-Prot factors calculated for seaweeds ranged between 4.51 (A. taxiformis) to 4.98 (C. clavulatum). An overall average N-Prot factor of 4.78 was calculated for all seaweed species.

For spermatophytes, amino acid-N ranged from $0.92 \%$ (L. racemosa) to $3.08 \%$ (R. maritima). The percentage of protein- $\mathrm{N}$ varied widely among the species, from $63.8 \%$ ( $T$. domingensis) to $97 \%$ (A. aureum). The species that presented more protein-N showed the highest N-Prot factors; conversely, the species with lower protein-N showed the smaller values for N-Prot factors. The N-Prot factors ranged from 3.97 (T. domingensis) to 6.00 (A. aureum). An overall average N-Prot factor of 4.82 was calculated from the data for all spermatophytes. 


\begin{tabular}{|c|c|c|c|c|}
\hline Groups/species & $\begin{array}{l}\text { Amino acid } \\
\text { residues }\end{array}$ & $\begin{array}{c}\text { Amino acid- } \\
\mathrm{N}\end{array}$ & Protein-N & N-Prot factor \\
\hline \multicolumn{5}{|l|}{ Seaweeds } \\
\hline Asparagopsis taxiformis & $25.1 \pm 2.07$ & $4.14 \pm 0.34$ & $74.5 \pm 6.14$ & $4.51 \pm 0.37$ \\
\hline Centroceras clavulatum & $23.0 \pm 0.68$ & $3.22 \pm 0.09$ & $69.5 \pm 2.04$ & $4.98 \pm 0.15$ \\
\hline Chaetomorpha aerea & $12.01 \pm 0.82$ & $1.94 \pm 0.13$ & $75.8 \pm 5.20$ & $4.69 \pm 0.32$ \\
\hline Sargassum filipendula & $8.62 \pm 0.33$ & $1.36 \pm 0.05$ & $78.0 \pm 2.96$ & $\begin{array}{l}4.93 \pm 0.19 \\
\text { Average: } 4.78\end{array}$ \\
\hline \multicolumn{5}{|l|}{ Spermatophytes } \\
\hline Halodule wrightii & $12.8 \pm 0.36$ & $2.13 \pm 0.06$ & $78.2 \pm 2.19$ & $4.69 \pm 0.13$ \\
\hline Ruppia maritima & $19.2 \pm 3.08$ & $3.08 \pm 0.22$ & $80.4 \pm 5.73$ & $5.02 \pm 0.36$ \\
\hline Acrostichum aureum & $10.4 \pm 0.98$ & $1.68 \pm 0.16$ & $97.0 \pm 9.15$ & $6.00 \pm 0.57$ \\
\hline Blutaparon portulacoides & $8.74 \pm 0.73$ & $1.37 \pm 0.11$ & $78.5 \pm 6.56$ & $5.01 \pm 0.42$ \\
\hline Typha domingensis & $9.96 \pm 1.34$ & $1.60 \pm 0.21$ & $63.8 \pm 8.56$ & $3.97 \pm 0.53$ \\
\hline Avicennia schaueriana & $8.08 \pm 0.17$ & $1.34 \pm 0.03$ & $68.9 \pm 1.46$ & $4.16 \pm 0.09$ \\
\hline Laguncularia racemosa & $5.56 \pm 0.34$ & $0.92 \pm 0.06$ & $93.0 \pm 5.75$ & $5.62 \pm 0.35$ \\
\hline Spartina alterniflora & $7.97 \pm 0.73$ & $1.29 \pm 012$ & $66.7 \pm 6.13$ & $\begin{array}{l}4.10 \pm 0.38 \\
\text { Average: } 4.82\end{array}$ \\
\hline \multicolumn{5}{|l|}{ Invertebrates } \\
\hline Desmapsamma anchorata & $19.4 \pm 1.10$ & $3.38 \pm 0.19$ & $89.2 \pm 5.05$ & $5.10 \pm 0.29$ \\
\hline Bunodosoma caissarum & $52.6 \pm 8.54$ & $9.51 \pm 1.55$ & $98.0 \pm 15.9$ & $5.41 \pm 0.88$ \\
\hline Aplysia brasiliana & $42.2 \pm 5.61$ & $7.30 \pm 0.97$ & $96.9 \pm 12.9$ & $5.61 \pm 0.75$ \\
\hline Eledone massyae & $66.7 \pm 10.4$ & $12.7 \pm 1.97$ & $99.7 \pm 15.5$ & $5.25 \pm 0.82$ \\
\hline Echinaster brasiliensis & $39.7 \pm 5.75$ & $7.49 \pm 1.08$ & $98.3 \pm 14.2$ & $5.21 \pm 0.75$ \\
\hline Echinometra lucunter & $29.6 \pm 2.42$ & $5.37 \pm 0.44$ & $98.9 \pm 8.08$ & $\begin{array}{l}5.46 \pm 0.45 \\
\text { Average: } 5.34\end{array}$ \\
\hline \multicolumn{5}{|l|}{ Fishes } \\
\hline Dactylopterus volitans & $70.2 \pm 7.82$ & $11.9 \pm 1.33$ & $101.4 \pm 11.3$ & $5.98 \pm 0.67$ \\
\hline Genypterus brasiliensis & $81.5 \pm 1.70$ & $13.9 \pm 0.29$ & $99.3 \pm 2.08$ & $5.80 \pm 0.12$ \\
\hline Mullus argentinae & $66.2 \pm 1.26$ & $11.4 \pm 0.22$ & $98.5 \pm 1.87$ & $5.69 \pm 0.11$ \\
\hline Rhizoprionodon lalandii & $79.3 \pm 1.06$ & $13.4 \pm 0.18$ & $92.9 \pm 1.24$ & $5.50 \pm 0.07$ \\
\hline Rhizoprionodon porosus & $80.5 \pm 9.69$ & $13.6 \pm 1.64$ & $91.4 \pm 11.0$ & $\begin{array}{l}5.39 \pm 0.65 \\
\text { Average: } 5.67\end{array}$ \\
\hline
\end{tabular}

Table 4. Calculation of nitrogen-to-protein conversion factors for twenty three marine organisms based on the amino acid residues to total nitrogen ratio. Values are expressed as percentage of the dry weight. Results represent the mean of three replicates $\pm \operatorname{SD}(n=3)$.

Nitrogen mass within total amino acid in invertebrates ranged from $3.38 \%$ (D. anchorata) to $12.7 \%$ (E. massyae). High values of protein nitrogen were estimated in invertebrates, ranged from $89.2 \%$ (D. anchoratta) to $99.7 \%$ (E. massyae). The N-Prot factors registered for invertebrates ranged from 5.10 to 5.61, with an overall average N-Prot factor of 5.34.

$\mathrm{N}$ mass in total amino acid of fishes ranged from $11.4 \%$ (M. argentinae) to $13.9 \%$ (G. brasiliensis). High values of protein-N were recovered, ranging from $91.4 \%$ (R. porosus) to $101.4 \%$ (D. volitans). The elasmobranch fishes (R. porosus and $R$. lalandii) showed the higher percentages of non proteinaceus nitrogen (NPN) (average 7.85\%). The N-Prot factors ranged between 5.39 ( $R$. porosus) to 5.98 (D. volitans). The elasmobranchs exhibited the lowest values of N-Prot factors. An overall average N-Prot factor of 5.67 was calculated for all fish species. 


\section{Discussion}

The chemical composition of marine organisms in general may be influenced by a number of factors such as physiological characteristics, habitat and life cycle, and environmental conditions. The chemical composition of algae and plants is directly influenced by environmental conditions of the site where they live (Kamer et al., 2004; Larcher, 2000), especially the availability of inorganic nutrients and light. On the other hand, the abiotic conditions seem to be less influential on animals: the chemical composition of invertebrates and vertebrates is more influenced by biological factors, such as diet, stage of life and reproductive cycle (Ogawa \& Maia, 1999).

\subsection{Nitrogen and phosphorus}

Wide differences in $\mathrm{N}$ and $\mathrm{P}$ tissue concentrations of seaweeds are related to taxonomic traits and species-specific capacities of taking up dissolved nutrients (Martínez-Aragón et al., 2002). Red algae tend to show higher $\mathrm{N}$ tissue concentrations than green and brown algae (Lourenço et al., 2002). Red algae contain phycoerithrin, a N-rich pigment that increases their nitrogen budget (Lobban \& Harrison, 1994), and the two red algae tested here are fast-growing species, which account for a higher $\mathrm{N}$ content in comparison to other species. Conversely, S. filipendula has a complex thallus and low rate of growth, showing a typically low content of $\mathrm{N}$ (Hwang et al., 2004). A similar trend can be extended to Chaetomorpha aerea, an alga that dwells a sandy substrate and it is partially burred.

Low concentrations of leaf nitrogen in spermatophytes (overall average of $2.18 \%$ ) can be considered as a general characteristic of plants, since several studies provided leaf $\mathrm{N}$ values similar to those reported in this study. According to Larcher (2000) leaves of herbaceous plants contain $2-4 \%$ in average $\mathrm{N}$, while leaves of deciduous plants contain 1.5 to $3 \% \mathrm{~N}$ and leaves of sclerophyllous plants contain 1 to $2 \% \mathrm{~N}$. Leaves of $T$. domingensis reached one of the largest concentrations of $\mathrm{N}$ among all plants tested. According to Lorenzen et al. (2001), Typha species are typically distributed in habitat rich in nutrients, which may explain the high levels of $\mathrm{N}$. The mangrove plants had low leaf $\mathrm{N}$ concentrations (and also low concentrations of carbohydrates, protein and total phosphorus). According to Erickson et al. (2004) leaves of Rhizophora mangle, Avicennia germinans and Laguncularia racemosa have N concentrations of 1.2, 1.8 and $1.0 \%$ (d.w.) respectively. Ellis et al. (2006) reported $\mathrm{N}$ percentages ranging from 0.75 to $1.25 \%$ in sheets of $L$. racemosa. Low percentages of $\mathrm{N}$ in mangrove plants may be related to the high concentration of salt in the leaves, since these plants accumulate salt in the leaves and then eliminate them (Hogarth, 1999). In addition, mangrove plants also have high concentration of tannin, polyphenols of plant origin that inhibit herbivory of the leaves. Erickson et al. (2004) estimated that tannin is an average of $20 \%$ of the d.w. of leaves of mangrove plants.

The high concentration of nitrogen observed in the animals is related with the abundance of protein in the tissues, its main component, and by the presence of OTMA (oxyde of trimethylamine), a nitrogenous substance widely found in marine animals (Ogawa \& Maia, 1999). The fishes and the octopus E. massyae showed $N$ concentrations significantly higher than the other animals, which may be related to the part of the body used in the analysis. We analyzed only the muscles of fishes, a procedure that reflects in the high protein concentration in the samples. In octopus, the mantle was the organ considered, which is predominantly composed of muscle (Brusca \& Brusca, 2003). Total $\mathrm{N}$ described in the muscles of fish, according to Ogawa \& Maia (1999) and Puwastien et al. (1999), varies circa 
$15 \%$ of the d.w. The highest concentrations of $\mathrm{N}$ were observed in the cartilaginous fish $R$. lalandii and $R$. porosus, which may be related to higher concentration of OTMA in elasmobranchs, where the substance associated with urea in the control of osmotic pressure (Ogawa \& Maia, 1999). Dantas \& Attayde (2007) and Sterner \& George (2000) also found high values of TN in freshwater fishes, with values fluctuating from $9.5 \%$ to $10.35 \%$ of d.w.

The peak in P concentration of seaweeds was recorded in C. clavulatum, a fast-growing red algae. S. filipendula showed the lowest $\mathrm{P}$ concentrations in its thallus, and this trend can also be interpreted as a consequence of its low growth rates. Chaetomorpha aerea showed the second highest $\mathrm{P}$ concentration. The occurrence of high tissue concentrations of phosphorus was recorded in three seaweeds that also live partially burred in sediments (Chaetomorpha crassa, Gracilaria cervicornis and Gracilariopsis tenuifrons) in a seasonal study in Araruama Lagoon, a hypersaline coastal environment of Brazil (Lourenço et al., 2005).

In spermatophytes, the highest concentrations of total $\mathrm{P}$ were found in seagrasses. These fast-growing plants experience a greater contact with dissolved nutrients, since they take up phosphorus from both soil and water. According to Reich \& Oleksyn (2004), herbs have higher concentrations of $\mathrm{N}$ and $\mathrm{P}$ than trees and shrubs. This observation may explain the higher contents of $\mathrm{N}$ and $\mathrm{P}$ in seagrasses, as well as in the salt marsh plant $S$. alterniflora.

Analysis of the phosphorus content in animals may be useful to interpret their metabolic speed. The highest concentration of $\mathrm{P}$ was recorded in fish and these high concentrations could be related to the characteristics of the tissues. Muscles of vertebrates store high potential phosphoryls in the form of creatinine-phosphate, which can quickly transfer its phosphate group to the ATP (Zeleznikar et al., 1995). Ogawa \& Maia (1999) state that animals that move fast spend more energy and use more ATP; this requires a greater supply of phosphorus in the muscles than animals of limited movements. In invertebrates, the wider variations in $\mathrm{P}$ content reflect their different capacities of locomotion. The low concentration of $\mathrm{P}$ in the sponge $\mathrm{D}$. anchorata may be related to a possible lower energy demand for (non-existing) locomotion, contrasting with the peak of phosphorus in the octopus E. massayae.

\subsection{Hydrosoluble protein, carbohydrate and lipid}

The availability of $\mathrm{N}$ is considered the most important factor influencing the levels of proteins in algae. N-poor environments tend to influence algal species to show low concentrations of protein, and the opposite is found in environments with high availability of N (Lobban \& Harrison, 1994; Lourenço et al., 2005, 2006). Measurements ranging from 3\% to more than $60 \%$ of the d.w. are documented in the literature. Methodological problems also contribute largely to enhance the differences among the results. Differences in cell wall composition and procedures used to extract proteins generate remarkable influence on the final results (Barbarino \& Lourenço, 2005; Fleurence, 1999).

Protein content of macroalgae from tropical and subtropical coastal environments frequently show low concentrations (Kaehler \& Kennish, 1996; Wong \& Cheung, 2000). Our data indicate low protein concentrations in the algae, which agrees with the predominantly oligotrophic condition of the Brazilian coastal waters (Lourenço et al., 2005, 2006). In general, the protein content of brown seaweeds is low (3-15\% of d.w.) compared to green and red seaweeds (10-47\% of the d.w.) (Fleurence, 1999; Rúperez \& Saura-Calixto, 2001), despite differences in species composition and seasonal periods (Fleurence, 1999). The level of hydrosoluble protein recorded in S. filipendula agrees with results found for the protein content of Sargassum species (Lourenço et al., 2002; McDermid \& Stuercke, 2003) and with 
the low TN content found in its thallus (Table 2). On the other hand, the red algae showed both protein content and TN concentrations higher than the other species tested here.

In general, plant leaves have lower concentrations of protein than macroalgae. Yeoh \& Wee (1994) analyzed the protein content of many angiosperms, and observed an average of $11 \%$ protein in their leaves. The value of protein described for the grass Spartina alterniflora is in agreement with the values reported by Yeoh \& Watson (1982), about 7.5\% dry weight. Seagrasses had the highest concentrations of TN protein in the leaves (average of 16\%). The opposite can be observed for mangrove and marsh plants, in which low concentrations of foliar $\mathrm{N}$ agree with low concentrations of leaf proteins.

Hydrosoluble protein in animal tissues was higher than in primary producers, indicating the protein as the main organic compound in the heterotrophic species tested, especially in fishes and in the octopus E. massyae. According to Rosa et al. (2005) the levels of soluble protein in cephalopods range from 50 to $75 \%$ of the d.w. of muscle. Concentrations of protein in fishes were similar to the results reported by Simões et al. (2007) and Zaboukas et al. (2006), who found values ca. $75 \%$ of d.w. The lowest protein concentration was found in M. argentinae, which can be related to the high lipid content of this species. Ogawa \& Maia (1999) state that there is a relationship between lipid and protein: if a large content of lipid are accumulates in fishes, the percentage of protein tend to decrease.

Carbohydrates are the most abundant substances in most photosynthetic organisms, since they occur in cell wall (e.g. cellulose, agar) and as storage products (ex.: starch, laminaran). In seaweeds, brown algae tend to show lower carbohydrate concentrations than other algal groups (Dawczynski et al., 2007) and the presence of less reactive carbohydrates may generate underestimates of total carbohydrate (Lobban \& Harrison, 1994). This might contribute to increase differences in comparison to both green and red algae. Kumari et al. (2010) investigated the carbohydrate contents in eighteen species of tropical seaweeds, and found contents ranging from 15 to 43; the value reported for Chaetomorpha spp. (30\%) was very similar to our data for C. aerea $(29.4 \%)$. The low concentration of carbohydrates in the mangrove plant $L$. racemosa, less than $10 \%$, may be related to high salt concentration in the leaves. Larcher (2000) states that plants that inhabit saline soils have high values of ash (up to $55 \%$ of the d.w.), and $\mathrm{Na}, \mathrm{Mg}, \mathrm{Cl}$ and $\mathrm{S}$ in quantities far above average.

All animal species analyzed showed low content of carbohydrate, especially the fishes and the octopus E. massyae. According to Ogawa \& Maia (1999) the presence of glycogen in the fish muscles is low, varying from 1.5 to $5 \%$ of carbohydrate (d.w.). There is a remarkable lack of data in the literature on carbohydrate in fishes, probably due the small importance of these substances for the nutritional value of fishes. The majority of the chemical studies with fish focus on the composition of protein and lipid (e.g. Puwastien et al., 1999; Simões et al., 2007). Invertebrates had more carbohydrate than fishes. The high levels of carbohydrate in Aplysia may be related to the secretion of mucopolysaccharides, characteristic of the subclass members Opisthobranchia (Brusca \& Brusca, 2003).

The fat concentration of seaweeds tended to be a little lower than in spermatophytes. The fat content of seaweeds typically accounts for 1-6\% of the d.w. (Fleurence et al., 1994; Gressler et al., 2010). The metabolism of benthic seaweeds involves the production of large amounts of carbohydrates as storage products (Lobban \& Harrison, 1994). The production of lipid is greater in planktonic algal species, in which they contribute for floating mechanisms. Altogether, seaweed species were low in fat and high in carbohydrate. Both lipid and carbohydrate contents recorded here agree with previous studies (e.g. Dawczynski et al., 2007; McDermid \& Stuercke, 2003; Rúperez \& Saura-Calixto, 2001). These studies reported 
crude lipid values in most seaweed predominantly lower than $5 \%$ of d.w. In our study, all seaweeds showed less than $5.5 \%$ of lipids.

Similarly to algae, spermatophytes stock carbohydrates in their tissues, especially polysaccharides. Fats and oils are important forms of carbon storage in seeds and fruits (Taiz \& Zeiger, 1998), but the present study focus on leaves only. The high concentration of carbohydrates, coupled with the trend that most plants stock lipids mainly in other organs, explain the low concentrations of lipids in leaves, an overall average of $5.21 \%$.

The concentrations of lipid were higher than the carbohydrate for all animal species, with exception of $A$. brasiliana. This trend results of the fact that animals store energy as fat content, converting the excess of sugar in fatty tissues. The highest concentration of lipids among all animals tested was found in the starfish E. brasiliensis. Moreover, Mathew et al. (1999), Özogul \& Özogul (2007), and Zaboukas et al. (2006) point that the percentages of lipid in animals are more influenced by the environmental conditions, feeding and physiological traits than the percentages of carbohydrate and protein. Mathew et al. (1999) and Ramos Filho et al. (2008) affirm that the concentrations of lipid in fish muscles vary from 0.3 to $20 \%$ (fresh weight). In our study, the average value for lipid content for the five fishes was $8.37 \%$ (d.w.) and M. argentinae showed a high lipid concentration (16.1\%, d.w.). The lowest concentrations of lipid were recorded in elasmobranch fishes (R. lalandii and $R$. porosus), fishes that store fat mainly in the liver (Ogawa \& Maia, 1999). Among the invertebrates, the octopus E. massyae had the lowest concentration of lipids. Cephalopods stock lipids in the digestive tract and typically have low concentrations of lipids in muscles (ca. 5\% d.w.) (Rosa et al., 2005). McClintock et al. (1990) also recorded high concentrations of lipids in the starfish Ophidiaster alexandri.

\subsection{Amino acids and total protein}

All organisms analyzed in this study had high concentrations of glutamic acid and low concentrations of histidine. The high concentrations of glutamic acid tend to occur because this AA is the precursor of the synthesis of all other AAs. The complexity of the biosynthesis of histidine usually leads to lower concentrations than non-essential AAs in plants, as reported by Noctor et al. (2002).

In general, algae and plants showed a similar pattern in the composition of AAs. Algae and plants showed high concentrations of aspartic acid, leucine, and glutamic acid and low levels of histidine and tyrosine. The main findings of amino acid composition of algal proteins described here are in agreement with previous studies (Dawczynski et al., 2007; Fleurence, 1999; Lourenço et al., 2002; Ramos et al., 2000; Wong \& Cheung, 2000). In general, all species are rich in the acidic amino acids, glutamic and aspartic acid and poor in histidine. Aspartic and glutamic acid constituted a substantial amount of total AA of seaweeds, ranging from $19.9 \%$ (A. taxiformis) to $27.6 \%$ (S. filipendula). These two amino acids contribute to the flavour-related properties characteristic of the marine products and are responsible for the special taste of seaweeds. The concentration of these two AA was higher in the brown alga S. filipendula than in red algae, as previously described by Dawczynski et al. (2007). The level of glutamic and aspartic acid together can represent up $26 \%$ and $32 \%$ of the total AA of the green algae Ulva rigida and $U$. rotundata (Fleurence et al, 1995). Lourenço et al. (2002) showed that values for aspartic and glutamic acid together varied from 20.8 to $31.1 \%$ in 19 species of seaweeds. The highest value of lysine was observed in C. aerea $(7.33 \%)$, in contrast to Ramos et al. (2000) who found in red algae higher values for lysine. 
The AAs found in higher concentrations in the leaves (glutamic acid and aspartic acid) together account for about $20 \%$ of total amino acids. Yeoh \& Watson (1982) reported that values of glutamic acid plus aspartic acid represent about $24 \%$ of the total content of AAs in leaves of grasses. The plant species analyzed had amino acid composition very similar. However, it is worth noticing the high concentration of proline recorded in leaves of $H$. wrightii and B. portulacoides. This may be related to the physiological adaptations to inhabit salt sites. According to Little (2000), some halophyte plants maintain their cytoplasm in the same osmotic pressure as the cell vacuole, accumulating free AAs such as proline. Martinelli et al. (2007) indicate that this feature in Sporobolus stapfianus, a halophilic grass, which accumulate AAs in vaculoes, especially proline, for adaptation to water stress.

The amino acid profiles of animals were more heterogeneous than that observed in algae and plants, since significant differences were observed in the concentrations of some AAs as glycine, lysine and arginine. The main findings of AA composition of fish proteins described here are in agreement with previous studies (Ogawa \& Maia, 1999; Uhe et al., 1992). In general, all fish species are rich in glutamic acid and lysine and poor in histidine. The sum of the most representative AAs (lysine and glutamic acid) in fish, indicate that these two amino acids represent more than $20 \%$ of all AAs. The octopus E. massyae showed similarities with the chemical composition of fish. However, the analysis of AAs allowed to observe that the mollusk are very rich in arginine, totaling nearly $18 \%$ of AAs. The starfish E. lucunter also showed a higher content of lysine $(8.31 \%$ of the total AA), while glycine achieved high concentration in the sponge $D$. anchorata. The remarkable differences in AA profiles of invertebrates possibly reflect phylogenetic traits (Dincer \& Cakli, 2007; Rosa et al., 2005).

Total protein was estimated by the sum of amino acid residues, which represents the actual protein in each sample (Aitken et al., 1991; Lourenço et al., 2004; Mossé, 1990). A remarkable difference between the protein concentrations obtained with Lowry's method and the sum of AA-Res was observed for photosynthetic organisms. The protein concentration estimated with Lowry's method achieved only about $50 \%$ in red algae in comparison with protein concentration estimated with total AA-Res. The possible cause for these differences could be related to difficulties in extraction of protein from freeze-dried samples, as demonstrated by Barbarino \& Lourenço (2005). Total amino acid analysis involves an acidic hydrolysis of the samples, which eliminates problems with protein extraction.

For three plant species (H. wrightii, R. maritima and B. portulacoides), the protein values calculated by the sum of AAs were higher than those recorded on Lowry et al. (1951). This trend could be faced as "normal", since not all protein can be extracted from the samples, especially in freeze-dried plant materials (Barbarino \& Lourenço, 2005). However, for leaves of mangrove and salt marsh species, the wetland plants A. aureum and T. domingensis, and the seaweed C. aerea the Lowry's method yielded a higher protein content. Recording higher concentrations of protein by Lowry's method compared to the estimate of total protein by the sum of AAs is not coherent. The need of a tricky extraction of protein in Lowry's method reduces the chances of recovering $100 \%$ of the protein content in a sample. In addition, the high concentration of protein indicated by the method of Lowry et al. (1951) in these species would be unsustainable, given the low concentration of $\mathrm{N}$ in these organisms (Table 2). Thus, it is assumed the presence of some interference in the sample that artificially raised the quantification of proteins. According to Zaia et al. (1998) the method of Lowry is subject to many interferences, where the presence of phenolic compounds, sugars, uric acid and melamine react with Folin-Ciocalteu reagent resulting in false positive. This method also receives interference by some inorganic ions such as 
potassium and magnesium (Stoscheck, 1990). As mentioned above, leaves of mangrove plants have high concentrations of tannin, which may be interfering in protein analysis by the method of Lowry. Abundant literature data support the interpretation that the sum of AA-Res yields a closer estimate of the actual protein content of plants, including mangrove samples. Erickson et al. (2004) reported that Rhizophora mangle, Avicennia germinans and Laguncularia racemosa have low concentrations of total protein, with respective figures of $6.5 \%, 8.5 \%$ and $6.5 \%$. These values were very similar to those reported in this study for total protein estimated by the sum of AAs.

Differences were also found for protein data in animals, with values protein obtained by the method of Lowry always lower (ca. 35\%) than that obtained by the sum of AA-Res. This trend is coherent with the nature of animal samples, which contents of protein are easier to extract and react, compared with plant materials. In addition, animal samples typically have less chemical interferences than algal and plant sources (Zaia et al., 1998).

\subsection{Nitrogen-to-protein conversion factors}

There are different ways to calculate N-Prot conversion factors. Several studies calculate the N-Prot factors as the ratio between AA-Res and TN (Fujihara et al., 2008; Levey et al., 2000; Matilla et al., 2002), such as it has been done in the present study. Other studies determined conversion factors taking into account the proportion between AAs and the recovery of $\mathrm{N}$ from the amino acids (AA-N) (Mossé, 1990; Sosulski \& Imafidon, 1990; Yeoh \& Wee, 1994). The conversion factor calculated based in N-AAs are higher than the factor calculated using $\mathrm{TN}$, thus the application of the conversion factor calculated only by AA-N can overestimate the actual protein content in the case of species with high NPN. This happens because the factor would multiply the TN content for calculating the percentage of protein, and TN does not distinguish between protein-N and NPN. For correct use of the conversion factor calculated with AA-N it is necessary to quantify protein-N from TN. However, this analysis is laborious and the use of this conversion factor would lose its practicability.

The total amino acid content represents not only amino acids derived from proteins, but also those AAs in free form. Free amino acids typically account for less than $7 \%$ of the total AA (Yeoh \& Watson, 1982). The presence of free amino acids contributes to an overestimation of the total protein. However, according to Mossé (1990), the use of data of total amino acid, without determination of free amino acids, is a widely accepted procedure to estimate protein, since in acid hydrolysis some not-abundant amino acids are partially or totally destroyed (e.g. tryptophan, cystine, methionine and serine). The loss during acid hydrolysis might compensate for the influence of free amino acids in the quantification of protein by the sum of the total amino acid residues.

It can be seen that the conversion factors N-Prot calculated for algae and plants were similar and lower than the factors calculated for the animals. Sosulski \& Imafidon (1990) and Tacon et al. (2009) compared the conversion factors in animal and vegetable products and found that the highest factors were calculated for animals. These observations can be explained mainly by the high concentration of NPN in photosynthetic organisms compared to the animals. The presence of photosynthetic pigments and the accumulation of inorganic nitrogen in the cells increase the relative importance of NNP in photosynthetic organisms. Lourenço et al. (2004) determined the concentration of NPN in 12 species of microalgae, with values ranging from $0.8 \%$ to $39 \%$ of the TN. Yeoh \& Wee (1994) indicated that the NNP represents about $24 \%$ of the TN in leaves. On the other hand, the quantity of NPN in 
muscles can vary from 6 to $14 \%$ of the total N (Puwastein et al., 1999). NPN in animals is present in the constitution of several substances, such as OTMA, amines, guanidines, nucleotids and their degrading products such as urea and ammonia. Other nonproteinaceous substances with nitrogen that can be present are glycilbetaine, carnitine and homarine (Ogawa \& Maia, 1999). The flavour of seafoods depends on the species, the fat content, and the presence and type of NPN compounds (Venugopal \& Shahidi, 1996).

Despite the great scientific and practical importance of this issue, so far only Aitken et al. (1991) and Lourenço et al. (2002) established specific N-Prot conversion factors for seaweeds. The overall mean N-Prot factor calculated in this report for four seaweeds was 4.78. Lourenço et al. (2002) reported an average N-Prot factor of 4.92 for 19 seaweeds, with average specific factors for groups: 5.13 for green algae; 5.38 for brown algae and 4.59 for red algae. Aitken et al. (1991) proposed mean N-Prot factor of 5.0 obtained for two species of Porphyra. Red algae tend to show larger amounts of NPN (30.5\% in C. clavulatum and 25.5 in A. taxiformis) than brown and green algae (22\% and $24.2 \%$, respectively). Current N-Prot factors are similar to those proposed by Lourenço et al. (2002) and Aitken et al. (1991).

Clear relationships were found between NPN and the conversion factors for spermatophytes. Plants with higher NPN had the lowest conversion factors (e.g. T. domingensis, A. schaueriana and S. alterniflora) and plants with less NPN had the highest conversion factors (e.g. A. aureum and L. racemosa). We observed a wide variation in the NProt factors calculated for plants, with an average of 4.82. Among the spermatophytes, we observed a wide variation in levels of NPN, with values ranging from $3 \%$ (A. aureum) to $36.2 \%$ (T. domingensis) of the TN, with an average of $21.7 \%$. This variation of NPN may be related to the hypothetical presence of abundant $\mathrm{N}$ compounds not measured here (e.g. inorganic nitrogen, chlorophylls). Alkaloids and glycosides also contain $\mathrm{N}$ and take part of the complex secondary products of plants (Fowden, 1981). The N-Prot factors calculated in this study are consistent with those described in the literature for plant species. Several studies have shown that for plant tissues, the conversion factor N-Prot varies from 3.7 to 6.0 (Fujihara et al. 2008; Levey et al. 2000; Mossé, 1990; Tacon et al., 2009; Yeoh \& Wee, 1994). Yeoh \& Wee (1994) proposed the use of average factor of 4.43 as a reliable estimate for the determination of proteins in plant leaves.

The animals showed higher conversion factors to those reported in photosynthetic organisms, a reflex of reduced concentrations of NPN in these organisms. An overall average of $3.6 \%$ of NPN was found in invertebrate and fish samples. Conversion factors calculated in this study for animals were similar among the species, where the factors ranged from de 5.10 (D. anchorata) to 5.98 (D. volitans). The overall mean N-Prot factors calculated in this report for invertebrates and fishes were 5.34 and 5.67, respectively. Among fishes, elasmobranchs had smaller N-Prot factors, achieving 5.39 and 5.50, for $R$. porosus e $R$. lalandii, respectively. This is possibly related to the higher concentration of NPN than in the other species. In cartilaginous fish, a smaller concentration of protein-N was estimated, which may be related to the high concentration of OTMA; a high concentration of urea can be found in muscles of elasmobranchs, achieving up to 2\% (Ogawa \& Maia, 1999). Despite the general high concentrations of protein- $\mathrm{N}$ in animals, all conversion factors calculated by us were lower than the traditional factor 6.25.

For animals, there were minor differences between the use of the factor 6.25 and the sum of AA-Res for the calculation of total protein. The factor 6.25 overestimates the protein content in fish samples in ca. 9\%. For elasmobranchs the overestimation is higher: $14 \%$. For invertebrates, the 6.25 factor overestimate the protein content between 10 and $20 \%$. Such 
differences are not neglectable, which means that the presence of NPN does affect the use of nitrogen-to-protein conversion factors in samples of marine animals.

Our results show clearly that the use of the traditional N-Prot factor of 6.25 overestimates the protein content of marine organisms. This statement can be illustrated by a simple hypothetical analysis, if someone estimates the content of protein of a given species of marine spermatophyte not studied here (e.g. a seagrass) from its $\mathrm{N}$ content. If the $\mathrm{N}$ percentage of this hypothetical plant is $2.0 \%$, the use of the traditional N-Prot factor (6.25) would give an estimate of protein content of $12.5 \%$. By the use of the specific N-Prot factors calculated by us (4.82), the estimate of the protein content would be $9.64 \%$.

In addition, specific N-Prot factors calculated here would receive minor influences of environmental conditions, despite possible changes in internal nitrogen budget. As the NProt factors result from the ratio of protein-N to total $\mathrm{N}$, organisms in N-rich environments tend to accumulate more nitrogen and also more protein- $\mathrm{N}$. In environments with scarce availability of nitrogen species would show lower contents of both total $\mathrm{N}$ and protein- $\mathrm{N}$ (Lourenço et al., 2002, 2005). These trends point for the wide use of specific N-Prot factors, which could be applied to species in different environmental conditions without restrictions.

\section{Conclusions}

This study shows wide variations in the gross chemical composition of organisms from coastal subtropical environments of Brazil. Seaweeds and spermatophytes showed higher concentrations of carbohydrate, but animals tended to show higher concentrations of protein, lipid, total nitrogen and total phosphorus.

Acidic amino acids dominate the profile of seaweeds and spermatophytes. In animals, other amino acids also show high concentrations, such as lysine in echinoderms and some species of fish.

In animals, more than $89 \%$ of the nitrogen is found in protein. Photosynthetic organisms show high and variable percentages of non-protein nitrogen, which may achieve more than $35 \%$ of the total nitrogen budget.

We recommend the use of the specific nitrogen-to-protein conversion factors calculated for each species studied here. For organisms not assessed in this study, we recommend the use of overall N-Prot factors estimated for the corresponding taxonomic groups (e.g. spermatophytes, fishes). The traditional factor 6.25 should be avoided, since it overestimates the protein concentration of marine organisms. The use of the N-Prot conversion factors calculated would yield more accurate protein analysis of marine organisms, contributing for better protein analysis in marine science.

\section{Acknowledgements}

Authors are indebted to Brazil's National Council for Scientific and Technological Development (CNPq) and Research Support Foundation of Rio de Janeiro State (FAPERJ) for the financial support of this study. GSD thanks Coordination of Improvement of Higher Education Personnel (CAPES) for her scholarship. Authors thank Dr. Renato Crespo Pereira (UFF) for the use of laboratory facilities and to Dr. Joel C. De-Paula (UNIRIO) for confirming the identification of the seaweeds. Thanks are due to Dr. João Oiano Neto and M.Sc. Sidney Pacheco (EMBRAPA) for running the amino acid analysis. 


\section{References}

Aitken, K.A.; Melton, L.D. \& Brown, M.T. (1991). Seasonal Protein Variation in the New Zealand Seaweeds Porphyra columbina Mont. and Porphyra subtumens J. Ag. (Rhodophyceae). Japanese Journal of Phycology, Vol.39, No.4, (December 1991), pp. 307-317, ISSN 0038-1578.

Amsler, C.D. (ed.) (2009). Algal Chemical Ecology. Springer-Verlag, ISBN 978-3-540-92998-7, Berlin, Germany.

Barbarino, E. \& Lourenço, S.O. (2005). An Evaluation of Methods for Extraction and Quantification of Protein from Macro- and Microalgae. Journal of Applied Phycology, Vol.17, No.5, (October 2005), pp. 447-460, ISSN 0921-8971.

Barbarino, E. \& Lourenço. S.O. (2009). Comparison of CHN Analysis and Hach Acid Digestion to Quantify Total Nitrogen in Marine Organisms. Limnology and Oceanography: Methods, Vol.7, No.11, (November 2009), pp. 751-760, ISSN 15415856.

Bradford, M. (1976). A Rapid and Sensitive Method for the Quantitation of Microgram Quantities of Protein Utilizing the Principle of Protein Dye-Binding. Analytical Biochemistry, Vol.72, No.1-2, (May 1976), pp. 248-254, ISSN 0003-2697.

Brusca, R.C. \& Brusca, G.J. (2003). Invertebrates. 2nd ed. Sinauer Associates, ISBN 0-87893-0973, Sunderland, U.S.A.

Carvalho, H.F. \& Recco-Pimentel, S.M. (eds.) (2007). A Célula. 2nd ed. Manole, ISBN 978-85204-2543-5, Barueri, Brazil.

Cohen, S.A. \& De Antonis, K.M. (1994). Applications of Amino Acid Derivatization with 6Aminoquinolyl-N-Hhydroxysuccinimidyl Carbamate. Analysis of Feed Grains, Intravenous Solutions and Glycoproteins. Journal of Chromatography A, Vol.661, No.1-2, (February 1994), pp. 25-34, ISSN 0021-9673.

Conklin-Brittain, N.L.; Dierenfeld, E.S.; Wranghan, R.W.; Norconk, M. \& Silver, S.C. (1999). Chemical Protein Analysis: a Comparasion of Kjeldhal Crude Protein and Total Ninhydrin Protein from Wild, Tropical Vegetation. Journal of Chemical Ecology, Vol.25, No.12, (December 1999), pp. 2601-2622, ISSN 0098-0331.

Dantas, M.C. \& Attayde, J.L. (2007). Nitrogen and Phosphorus Content of Some Temperate and Tropical Freshwater Fishes. Journal of Fish Biology, Vol.70, No.1, (January 2007), pp. 100-108, ISSN 1095-8649.

Dawczynski, C.; Schubert, R. \& Jahreis, G. (2007). Amino Acids, Fatty Acids, and Dietary Fiber in Edible Seaweed Products. Food Chemistry. Vol.103, No.3, (March 2007), pp. 891-899, ISSN 0308-8146.

Dincer, T. \& Cakli, S. 2007. Chemical Composition and Biometrical Measurements of the Turkish Sea Urchin (Paracentrotus lividus, Lamarck, 1816). Critical Reviews in Food Science and Nutrition. Vol.47, No.1 (January 2007), pp. 21-26, ISSN 1040-8398.

Diniz, G.S.; Barbarino, E.; Oiano-Neto, J.; Pacheco, S. \& Lourenço. S.O. (2011). Gross Chemical Profile and Calculation of Nitrogen-to-Protein Conversion Factors for Five Tropical Seaweeds. American Journal of Plant Sciences, in press, ISSN 21582750.

Duarte, C.M.; Augustí, S.; Berelson, W.; Gnanadesikan, A.; Regaudie-de-Gioux, S.A.; Sarmiento, J.L.; Simó, R. \& Slater, R.D. (eds.) (2011). The Role of the Marine Biota on the Functioning of the Biosphere. Fundación BBVA, ISBN 978-84-92937-04-2. Bilbao, Spain. 
Dubois, M.; Gilles, K.A.; Hamilton, J.K.; Rebers, P.A. \& Smith, F. (1956). Colorimetric Method for Determination of Sugars and Related Substances. Analytical Chemistry, Vol.28, No.3, (March 1956), pp. 350-356, ISSN 003-2700.

Ellis, W.L.; Bowles, J.W.; Erickson, A.A.; Stafford, N.; Bell, S.S. \& Thomas, M. (2006). Alteration of the Chemical Composition of Mangrove (Laguncularia racemosa) Leaf Litter Fall by Freeze Damage. Estuarine, Coastal and Shelf Science, Vol.68, No.1-2, (June 2006) pp. 363-371, ISSN 0272-7714.

Erickson, A.A.; Bella, S.S. \& Dawes, C.J. (2004). Does Mangrove Leaf Chemistry Help Explain Crab Herbivory Patterns? Biotropica, Vol.36, No.3, (September 2004), pp. 333-343, ISSN 1744-7429.

Fleurence, J. (1999). Seaweeds Proteins: Biochemical, Nutritional Aspects and Potential Uses. Trends Food Science Technology, Vol.10, No.1, (January 1999), pp. 25-28, ISSN 09242244.

Fleurence, J.; Gutbier, G.; Mabeu, S. \& Leray, C. (1994). Fatty Acids from 11 Marine Macroalgae of the French Brittany Coast. Journal of Applied Phycology, Vol.6, No.5-6, (December 1994), pp. 527-532, ISSN 0921-8971.

Fleurence, J.; Le Couer, C.; Mabeau, S.; Maurice, M. \& Landrein, A. (1995). Comparison of Different Extractive Procedures for Proteins from the Edible Seaweeds Ulva rigida and Ulva rotundata. Journal of Applied Phycology, Vol.7, No.6, (December 1995), pp. 577-582, ISSN 0921-8971.

Folch, J.; Lees, M. \& Sloanne-Stanley, G.H. (1957). A Simple Method for the Isolation and Purification of Total Lipid from Animal Tissue. The Journal of Biological Chemistry, Vol.226, No.1, (May 1957), pp. 497-509, ISSN 0021-9258.

Fowden, L. (1981). Non-Protein Amino Acids of Plants. Food Chemistry, Vol.6, No.3, (March 1981), pp. 201-211, ISSN 0308-8146.

Fujihara, S.; Sasaki, H.; Aoyagi, Y. \& Sugahara, T. (2008). Nitrogen-to-Protein Conversion Factors for Some Cereal Products in Japan. Journal of Food Science, Vol.73, No.1, (February 2008), pp. 204-209, ISSN 0022-1147.

Gressler, V.; Yokoya, N.S.; Fujii, M.T.; Colepicolo, P.; Mancini Filho, J.; Torres R.P. \& Pinto, E. (2010). Lipid, Fatty Acid, Protein, Amino Acid and Ash Contents in Four Brazilian Red Algae Species. Food Chemistry, Vol.120, No.2, (May 2010), pp. 585-590, ISSN 0308-8146.

Hedges, J., Peterson, M.L., \& Wakeham, S.G. (2002). The Biochemical and Elemental Compositions of Marine Plankton: A NMR Perspective. Marine Chemistry, Vol.78, No.1, (April 2002), pp. 47-63, ISSN 0304-4203.

Hogarth, P.J. (1999). The Biology of Mangroves. Oxford University Press, ISBN 0-19-850222-2, Oxford, U.K.

Hwang, R.-L.; Tsai, C.-C. \& Lee, T.-M. (2004). Assessment of Temperature and Nutrient Limitation on Seasonal Dynamics Among Species of Sargassum from a Coral Reef in Southern Taiwan. Journal of Phycology, Vol.40, No.3, (June 2004), pp. 463-473, ISSN 0022-3646.

Janecki, T. \& Rakusa-Suszczewski, S. (2004). Chemical Composition of the Antarctic Starfish Odontaster validus (Koehler 1911) and Its Reactions to Glutamic and Kynurenic Acids. Russian Journal of Marine Biology, Vol.30, No.5, (September 2004) pp. 358-360, ISSN 1063-0740. 
Jones, D.B (1931). Factors for Converting Percentages of Nitrogen in Foods and Feeds into Percentages of Protein. United State Department of Agriculture Circular, Vol. 183, (August 1931), pp. 1-21, ISSN 1052-5378.

Kaehler, S. \& Kennish, R. (1996). Summer and Winter Comparisons in the Nutritional Value of Marine Macroalgae from Hong Kong. Botanica Marina, Vol.39, No.1, (January 1996), pp. 11-17, ISSN 0006-8055.

Kamer, K.; Fong, P.; Kennison, R. \& Schiff, K. (2004). The Relative Importance of Sediment and Water Column Supplies of Nutrients to the Growth and Tissue Nutrient Content of the Green Macroalga Enteromorpha intestinalis Along an Estuarine Resource Gradient. Aquatic Ecology, Vol.38, No.1, (March 2004), pp. 45-56, ISSN 1386-2588.

Karl, D.; Michaelis, A.; Bergman, B.; Capone, D.; Carpenter, E.; Letelier, R.; Lipschultz, F.; Paerl, H.; Sigman, D. \& Stal, L. (2002). Dinitrogen Fixation in the World's Oceans. Biogeochemistry, Vol.57/58, No.1, (April 2002), pp. 47-98, ISSN 1386-2588.

Kumari, P.; Kumar, M.; Gupta, V.; Reddy, C.R.K. \& Jha, B. (2010). Tropical Marine Macroalgae as Potential Sources of Nutritionally Important PUFAs. Food Chemistry, Vol.120, No.3., (June 2010), pp. 749-757, ISSN 0308-8146.

Larcher, W. (2000). Ecofisiologia Vegetal. RiMa, ISBN 85-86552-03-8, São Carlos, Brazil.

Legler, G.; Müller-Platz, C.M.; Mentges-Hettkamp, M.; Pflieger, G. \& Jülich, E. (1985). On the Chemical Basis of the Lowry Protein Determination. Analytical Biochemistry, Vol.150, No.2, (November 1985), pp. 278-287, ISSN 0003-2697.

Levey, D.J.; Bissell, H.A. \& O'Keefe, S.F. (2000). Conversion of Nitrogen to Protein and Amino Acids in Wild Fruits. Journal of Chemical Ecology, Vol.26, No.7, (July 2000), pp. 1749-1763, ISSN 0098-0331.

Little, C. (2000). The Biology of Shoft Shores and Estuaries. Oxford University Press, ISBN 0-19850426-8, Oxford, U.K.

Lobban, C. S. \& Harrison, P.H. (1994). Seaweed Ecology and Physiology. Cambridge University Press, ISBN 0-521-40897-0, New York, USA.

Lorenzen, B.; Brix, H.; Mendelssohn, I.A.; McKee, K.L. \& Miao, S.L. (2001). Growth, Biomass Allocation and Nutrition Use Efficiency in Cladium jamaicense and Typha domingensis as Affected by Phosphorus and Oxygen Availability. Aquatic Botany, Vol.70, No.2, (June 2001), pp. 117-133, ISSN 0304-3770.

Lourenço, S.O.; Barbarino, E.; De-Paula, J.C.; Pereira, L.O. da S. \& Lanfer Marquez, U.M. (2002). Amino Acid Composition, Protein Content and Calculation of Nitrogen-toProtein Conversion Factors for 19 Tropical Seaweeds. Phycology Research, Vol.50, No.3, (September 2002), pp. 233-241, ISSN 1322-0829.

Lourenço, S.O.; Barbarino, E.; Lavín, P.L.; Marquez, U.M.L. \& Aidar, E. (2004). Distribution of Intracellular Nitrogen in Marine Microalgae. Calculation of New Nitrogen-toProtein Conversion Factors. European Journal of Phycology, Vol.39, No.1, (February 2004), pp. 17-32, ISSN 0967-0262.

Lourenço, S.O.; Barbarino, E.; Nascimento, A. \& Paranhos, R. (2005). Seasonal Variations in Tissue Nitrogen and Phosphorus of Eight Macroalgae from a Tropical Hypersaline Coastal Environment. Cryptogamie Algologie, Vol.26, No.4, (November 2005), pp. 355-371, ISSN 0181-1568. 
Lourenço, S.O.; Barbarino, E.; Nascimento, A.; Freitas, J.N.P. \& Diniz, G.S. (2006). Tissue Nitrogen and Phosphorus in Seaweeds in a Tropical Eutrophic Environment: What a Long-Term Study Tells Us. Journal of Applied Phycology, Vol.18, No.4, (October 2006), pp. 389-398, ISSN 0921-8971.

Lowry, O.H.; Rosebrough, N.J.; Farr, A.L. \& Randall, R.L. (1951). Protein Measurement with the Folin Phenol Reagent. The Journal of Biological Chemistry, Vol.193, No.1, (May 1951), pp. 265-275, ISSN 0021-9258.

Mariotti, F.; Tomé, D. \& Mirand, P.P. (2008). Converting Nitrogen into Protein-Beyond 6.25 and Jones' Factors. Critical Reviews in Food Science and Nutrition, Vol.48, No.2, (February 2008), pp. 177-184, ISSN 1040-8398.

Martinelli, T.; Whittaker, A.; Bochicchio, A.; Vazzana, C.; Suzuki, A. \& Masclaux-Daubresse, C. (2007). Amino Acid Pattern and Glutamate Metabolism During Dehydration Stress in the "Resurrection" Plant Sporobolus stapfianus: A Comparison Between Desiccation-Sensitive and Desiccation-Tolerant Leaves. Journal of Experimental Botany, Vol.58, No.11, (August 2007), pp. 3037-3046, ISSN 0022-0957.

Martínez-Aragón, J.F.; Hernández, I.; Pérez-Looréns, J.L.; Vázquez, R. \& Vergara, J.J. (2002). Biofiltering Efficiency in Removal of Dissolved Nutrients by Three Species of Estuarine Macroalgae Cultivated with Sea Bass (Dicentrarchus labrax) Waste Waters 1. Phosphate. Journal of Applied Phycology, Vol.14, No.5, (October 2002), pp. 365-374, ISSN 0921-8971.

Mathew, S.; Ammu, K.; Viswanathan Nair, P.G. \& Devadasan, K. (1999). Cholesterol Content of Indian Fish and Shellfish. Food Chemistry, Vol.66, No.4, (September 1999), pp. 455-461, ISSN 0308-8146.

Mattila, P.; Salo-Väänänen, P.; Könkö, K.; Aro, H. \& T. Jalava. (2002). Basic Composition and Amino Acid Contents of Mushrooms Cultivated in Finland. Journal of Agricultural and Food Chemistry, Vol.50, No.22, (October 2002), pp. 6419-6422, ISSN 0021-8561.

McClintock, J.B.; Cameron, J.L. \& Young, C.M. (1990). Biochemical and Energetic Composition of Bathyal Echinoids and an Asteroid, Holothuroid and Crinoid from the Bahamas. Marine Biology, Vol.105, No.2, (June 1990), pp. 175-183, ISSN 00253162.

McDermid, K.J. \& Stuercke, B. (2003). Nutritional Composition of Edible Hawaiian Seaweeds. Journal of Applied Phycology, Vol.15, No.6, (November 2003), pp. 513-524, ISSN 0921-8971.

Mossé, J. (1990). Nitrogen to Protein Conversion Factor for Ten Cereals and Six Legumes or Oilseeds. A Reappraisal of its Definition and Determination. Variation According to Species and to Seed Proteic content. Journal of Agricultural and Food Chemistry, Vol.38, No.1, (January 1990), pp. 18-24, ISSN 0021-8561.

Myklestad, S. \& Haug, A. (1972). Production of Carbohydrates by the Marine Diatom Chaetoceros affinis var. willei (Gran) Hustedt. I. Effect of the Concentration of Nutrients in the Culture Medium. Journal of Experimental Marine Biology and Ecology, Vol.9, No.2, (August 1972), pp. 125-136, ISSN 0022-0981.

Noctor, G.; Novitskaya, L.; Lea, P.J. \& Foyer, C.H. (2002). Co-Ordination of Leaf Minor Amino Acid Contents in Crop Species: Significance and Interpretation. Journal of Experimental Botany, Vol.53, No.370, (April 2002), pp. 939-945, ISSN 0022-0957. 
Nurnadia, A.A.; Azrina, A. \& Amin, I. (2011). Proximate Composition and Energetic Value of Selected Marine Fish and Shellfish from the West Coast of Peninsular Malaysia. International Food Research Journal, Vol.18, No.1, (January 2011), pp 137-148, ISSN 1985-4668.

Ogawa, M. \& Maia, E.L. 1999. Manual de Pesca - Ciência e Tecnologia do Pescado. Editora Varela, ISBN 85-855-1944-4, São Paulo, Brazil.

Özogul, Y. \& Özogul, F. (2007). Fatty Acid Profiles of Commercially Important Fish Species from the Mediterranean, Aegean and Black Seas. Food Chemistry, Vol.100, No.4, (December 2007), pp. 1634-1638, ISSN 0308-8146.

Puwastien, P.; Judprasong, K.; Kettwan, E.; Vasanachitt, K.; Nakngamanong, Y. \& Bhattacharjee, L. (1999). Proximate Composition of Raw and Cooked Thai Freshwater and Marine Fish. Journal of Food Composition and Analysis, Vol.12, No.1, (March 1999), pp 9-16, ISSN 0889-1575.

Ramos Filho, M.M.; Ramos, M.I.L.; Hiane P.A. \& Souza. E.M.T. (2008). Perfil Lipídico de Quatro Espécies de Peixes da Região Pantaneira de Mato Grosso do Sul. Ciência e Tecnologia de Alimentos, Vol.28, No.2, (April 2008), pp. 361-365, ISSN 0101-2061.

Ramos, M.V.; Monteiro, A.C.O.; Moreira, R.A. \& Carvalho, A.F.F.U. (2000). Amino Acid Composition of Some Brazilian Seaweed Species. Journal of Food Biochemistry, Vol.24, No.1, (March 2000), pp. 33-39, ISSN 0145-8884.

Reich, P.B. \& Oleksyn, J. (2004). Global Patterns of Plant Leaf N and P in Relation to Temperature and Latitude. Proceedings of the National Academy of Sciences of the United States of America, Vol.101, No.30, (June 2004), pp. 11001-11006, ISSN 00278424.

Rosa, R.; Pereira, J. \& Nunes, M.L. (2005). Biochemical Composition of Cephalopods with Different Life Strategies, with Special Reference to Giant Squid, Architeuthis sp. Marine Biology, Vol. 146, No.4, (March 2005), pp. 739-751, ISSN 0025-3162.

Rúperez, P. \& Saura-Calixto, F. (2001). Dietary Fibre and Physicochemical Properties of Edible Spanish Seaweeds. European Food Research and Technology, Vol.212, No.3, (February 2001), pp. 349-354, ISSN 1438-2377.

Salo-Väänänen, P.P. \& Koivistoinen, P.E. (1996). Determination of Protein in Foods: Comparison of net Protein and Crude Protein ( $\mathrm{N} x$ 6.25) Values. Food Chemistry, Vol.57, No.1, (September 1996), pp. 27-31, ISSN 0308-8146.

Simões, M.R.; Ribeiro, C.F.A.; Ribeiro, S.C.A.; Park K.J. \& Murr, E.X. (2007). Composição Físico-Química, Microbiológica e Rendimento do Filé de Tilápia Tailandesa (Oreochromis niloticus). Ciência e Tecnologia de Alimentos, Vol.27, No.3, (July/September 2007), pp. 608-613, ISSN 0101-2061.

Sosulski, F.W. \& Imafidon. G.I. (1990). Amino Acid Composition and Nitrogen-to-Protein Conversion Factors for Animal and Plant Foods. Journal of Agricultural and Food Chemistry, Vol.38, No.6, (June 1990), pp. 1351-1356, ISSN 0021-8561.

Sterner, R.W. \& George, N.B. (2000). Carbon, Nitrogen and Phosphorus Stoichiometry of Cyprinid Fishes. Ecology, Vol.81, No.1, (January 2000), pp. 127-140, ISSN 0012-9658.

Stoscheck, C.M. (1990). Quantification of Protein. Methods in Enzimology, Vol.182, No.1, pp. 50-68, ISSN 0076-6879.

Tacon. A.G.J.; Metian, M. \& Hasan, M.R. (2009). Feed Ingredients and Fertilizers for Farmed Aquatic Animals. Sources and Composition. FAO Fisheries and Aquaculture Technical Paper No. 540, ISBN 978-92-5-106421-4, Rome, Italy. 
Taiz, L. \& Zeiger, E. (1998). Plant Physiology. 2nd ed. Sinauer Associates, ISBN 0-87893-831-1, Sunderland, USA.

Uhe, A.M.; Collier, G.R. \& O'Dea, K. 1992. A Comparison of the Effects of Beef, Chicken and Fish Protein on Satiety and Amino Acid Profiles in Lean Male Subjects. The Journal of Nutrition, Vol.122, No.3, (March 1992), pp. 467-472, ISSN 0022-3166.

Undeland, I.; Hall, G. \& Lingnert, H. (1999). Lipid Oxidation in Fillets of Herring (Clupea harengus) During Ice Storage. Journal of Agricultural and Food Chemistry, Vol.47, No.2, (February 1999), pp. 524-532, ISSN 0021-8561.

Venugopal, V. \& Shahidi. F. (1996). Structure and Composition of Fish Muscle. Food Reviews International, Vol.12, No.2, pp. 175-197, ISSN 8755-9129.

Wong, K.H. \& Cheung, C.K. (2000). Nutritional Evaluation of Some Subtropical Red and Green Seaweeds. Part I - Proximate Composition, Amino Acid Profiles and Some Physico-Chemical Properties. Food Chemistry, Vol.71, No.1, (December 2000), pp. 475-482, ISSN 0308-8146.

Yeoh, H.H. \& Truong, V.D. (1996). Amino Acid Composition and Nitrogen-to-Protein Conversion Factors for Sweet Potato. Tropical Science, Vol.36, No.4, (November 1996), pp. 243-246, ISSN 0041-3291.

Yeoh, H.H. \& Watson, L. (1982). Taxonomic Variation in Total Leaf Protein Amino Acid Compositions of Grasses. Phytochemistry, Vol.21, No.3, (March 1982), pp. 615-626, ISSN 0031-9422.

Yeoh, H.H. \& Wee, Y.C. (1994). Leaf Protein Contents and Nitrogen-to-Protein Conversion factors for 90 Plant Species. Food Chemistry, Vol.49, No.3, (February 1994), pp. 245250, ISSN 0308-8146.

Zaboukas, N.; Miliou, H.; Megalofonou, P. \& Moraitou-Apostolopoulou, M. (2006). Biochemical Composition of the Atlantic Bonito Sarda sarda from the Aegean Sea (Eastern Mediterranean Sea) in the Different Stages of Sexual Maturity. Journal of Fish Biology, Vol.69, No.2, (August 2006), pp. 347-362, ISSN 0022-1112.

Zaia, D.A.M.; Zaia, C.T.B.V. \& Lichting, J. (1998). Determinação de Proteínas Totais Via Espectrofotometria: Vantagens e Desvantagens dos Métodos Existentes. Química Nova, Vol.21, No.6, (November/December 1998), pp. 787-793, ISSN 0100-4042.

Zar, J.H. (1996). Biostatistical Analysis. 3rd ed. Prentice Hall, ISBN 0130-84542-6, Upper Saddle River, U.S.A.

Zeleznikar, R.J.; Dzeja, P.P. \& Goldberg, N.D. (1995). Adenylate Kinase-Catalyzed Phosphoryl Transfer Couples ATP Utilization with its Generation by Glycolysis in Intact Muscle. Journal of Biological Chemistry, Vol.270, No13, (March 1995), pp. 73117319, ISSN 0021-9258. 


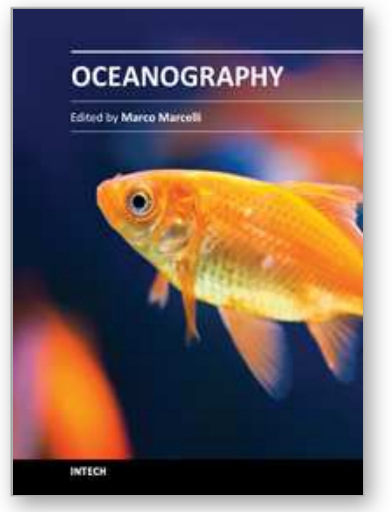

\author{
Oceanography \\ Edited by Prof. Marco Marcelli
}

ISBN 978-953-51-0301-1

Hard cover, 348 pages

Publisher InTech

Published online 23, March, 2012

Published in print edition March, 2012

How inappropriate to call this planet Earth when it is quite clearly Ocean (Arthur C. Clarke). Life has been originated in the oceans, human health and activities depend from the oceans and the world life is modulated by marine and oceanic processes. From the micro-scale, like coastal processes, to macro-scale, the oceans, the seas and the marine life, play the main role to maintain the earth equilibrium, both from a physical and a chemical point of view. Since ancient times, the world's oceans discovery has brought to humanity development and wealth of knowledge, the metaphors of Ulysses and Jason, represent the cultural growth gained through the explorations and discoveries. The modern oceanographic research represents one of the last frontier of the knowledge of our planet, it depends on the oceans exploration and so it is strictly connected to the development of new technologies. Furthermore, other scientific and social disciplines can provide many fundamental inputs to complete the description of the entire ocean ecosystem. Such multidisciplinary approach will lead us to understand the better way to preserve our "Blue Planet": the Earth.

\title{
How to reference
}

In order to correctly reference this scholarly work, feel free to copy and paste the following:

Graciela S. Diniz, Elisabete Barbarino and Sergio O. Lourenço (2012). On the Chemical Profile of Marine Organisms from Coastal Subtropical Environments: Gross Composition and Nitrogen-to-Protein Conversion Factors, Oceanography, Prof. Marco Marcelli (Ed.), ISBN: 978-953-51-0301-1, InTech, Available from: http://www.intechopen.com/books/oceanography/on-the-chemical-profile-of-marine-organisms-from-coastalsubtropical-environments-gross-composition-

\section{INTECH}

open science | open minds

\section{InTech Europe}

University Campus STeP Ri

Slavka Krautzeka 83/A

51000 Rijeka, Croatia

Phone: +385 (51) 770447

Fax: +385 (51) 686166

www.intechopen.com

\section{InTech China}

Unit 405, Office Block, Hotel Equatorial Shanghai

No.65, Yan An Road (West), Shanghai, 200040, China 中国上海市延安西路65号上海国际贵都大饭店办公楼 405 单元

Phone: $+86-21-62489820$

Fax: +86-21-62489821 
(C) 2012 The Author(s). Licensee IntechOpen. This is an open access article distributed under the terms of the Creative Commons Attribution 3.0 License, which permits unrestricted use, distribution, and reproduction in any medium, provided the original work is properly cited. 